\title{
O-H-Sr-Nd isotope constraints on the origin of the Famatinian magmatic arc, NW Argentina
}

\author{
Alasino, P. ${ }^{1-2}$, Casquet, C. ${ }^{3}$, Galindo C. ${ }^{3}$, Pankhurst R. ${ }^{4}$, Rapela C. ${ }^{5}$, Dahlquist J. ${ }^{6}$, Recio C. ${ }^{7}$, \\ Baldo. E. ${ }^{6}$ Larrovere, M. ${ }^{1-2}$, Ramacciotti, C. ${ }^{6}$ \\ ${ }^{1}$ Centro Regional de Investigaciones Científicas y Transferencia Tecnológica de La Rioja (CRILAR), Prov. de La \\ Rioja-UNLaR-SEGEMAR-UNCa-CONICET, Entre Ríos y Mendoza, 5301, Anillaco, La Rioja, Argentina \\ ${ }^{2}$ Instituto de Geología y Recursos Naturales (INGeReN), CENIIT-UNLaR, Av. Gobernador Vernet y Apóstol Felipe, \\ 5300, La Rioja, Argentina \\ ${ }^{3}$ Departamento de Mineralogía y Petrología, Univ. Complutense, Instituto de Geociencias (CSIC-UCM), 28040 \\ Madrid, Spain \\ ${ }^{4}$ Visiting Research Associate, British Geological Survey, Keyworth, Nottingham NG12 5GG, UK \\ ${ }^{5}$ Centro de Investigaciones Geológicas (CIG), CONICET-UNLP, Calle 1 No. 644, 1900, La Plata, Argentina \\ ${ }^{6}$ Centro de Investigaciones en Ciencias de la Tierra (CICTERRA). CONICET-UNC. Av. Vélez Sarsfield 1611. \\ Ciudad Universitaria X5016GCA, Argentina \\ ${ }^{7}$ Area de P. y Geoquímica, Dto. de Geología, Univ. de Salamanca Pza. de los Caídos, S/N E-37008 Salamanca, \\ Spain
}

Short title: Origin of the Famatinian magmatism in NW Argentina

Email address for the corresponding author: palasino@conicet.gov.ar 


\section{ABSTRACT}

We report a study of whole-rock O-H-Sr-Nd isotopes of Ordovician igneous and metamorphic rocks exposed at different crustal paleo-depths along ca. $750 \mathrm{~km}$ in the Sierras Pampeanas, NW Argentina. The isotope compositions preserved in the intermediate rocks (mostly tonalite) (av. $\delta^{18} \mathrm{O}=+8.7 \pm 0.5 \%, \delta \mathrm{D}=-73 \pm 14 \%{ }^{87} \mathrm{Sr} /{ }^{86} \mathrm{Sr}_{\mathrm{t}}=0.7088 \pm 0.0001$ and $\left.\varepsilon \mathrm{Nd}_{\mathrm{t}}=-4.5 \pm 0.6\right)$ show no major difference from those of most of the mafic rocks (av. $\delta^{18} \mathrm{O}=+8 \pm 0.8 \%$, $\delta \mathrm{D}=-84 \pm 18 \%$, ${ }^{87} \mathrm{Sr} /{ }^{86} \mathrm{Sr}_{\mathrm{t}}=0.7082 \pm 0.0016$ and $\left.\varepsilon \mathrm{Nd}_{\mathrm{t}}=-4 \pm 1.1\right)$, suggesting that the most of their magmas acquired their "crustal" characteristics in the mantle. The estimate of assimilation of crustal material $\left(\delta^{18} \mathrm{O}=+12.2 \pm 1.7 \%\right.$ o, $\delta \mathrm{D}=-89 \pm 21 \%{ }^{87}{ }^{87} \mathrm{Sr}^{86} \mathrm{Sr}_{\mathrm{t}}=0.7146 \pm 0.0034$ and $\left.\varepsilon \mathrm{Nd}_{\mathrm{t}}=-6.9 \pm 0.7\right)$ by the tonalite is in most samples within the range $10-15 \%$. Felsic magmas that reached upper crustal levels had isotope values $\left(\delta^{18} \mathrm{O}=9.9 \pm 1.5 \%, \delta \mathrm{D}=-76 \pm 5 \%,{ }^{87} \mathrm{Sr} /{ }^{86} \mathrm{Sr}_{\mathrm{t}}=0.7067 \pm 0.0010\right.$, $\left.\varepsilon \mathrm{Nd}_{\mathrm{t}}=-3.5 \pm 1.4\right)$ that suggest that they were not derived by fractionation of the contaminated intermediate magmas, but evolved from different magma batches. Some rocks of the arc, both igneous (mostly gabbro and tonalite) and metamorphic, underwent restricted interaction with meteoric fluids. Reported values of $\delta^{18} \mathrm{O}$ of magmatic zircons from the Famatinian arc rocks $(+6$ to $+9 \%$ ) are comparable to our $\delta^{18} \mathrm{O}$ whole-rock data, indicating that pervasive oxygen isotope exchange in the lower crust was not a major process after zircon crystallization.

Keywords: Famatinian arc magmatism; stable and radiogenic isotopes; continental growth; nonhomogenized magmatic system 


\section{Introduction}

The generation of intermediate rocks has been of great interest in modern geology because they are an essential component in the formation of the continental crust in Cordilleran-type arcs. Unlike felsic rocks that can be related to anatexis of supracrustal rocks or to fractional crystallization of mafic magma (e.g. Jagoutz and Klein 2018 and references therein), the formation of intermediate (mostly tonalitic) rocks in Cordilleran-type magmatic arcs is still under discussion. A large number of hypotheses have been proposed for their origin, including: (i) fractional crystallization of primary melts (e.g. Arth et al. 1978; Gill 1981; Rogers \& Hawkesworth 1989; Müntener et al. 2001; Grove et al. 2003); (ii) partial melting of a variety of different sources, including mantle material (e.g. Moorbath 1975; Evans \& Hanson 1996), amphibolite and eclogite (e.g. Rapp et al. 1991); (iii) mixing of basaltic magmas with crustal melts in a deep crustal hot zone (e.g. De Paolo 1981; Annen et al. 2006) and (iv) processes within the mantle by partial melting and/or reaction with subducted materials (Castro 2014).

The recognition of different "types" of tonalitic rocks implies more than one origin for the generation of tonalite magma. There is a consensus that the asthenospheric mantle is the source region for the most isotopically juvenile magmatism in Cordilleran magmatism (Grove et al. 2012), but less agreement exists about the origin of the isotopically evolved end-members. Most of the proposed petrogenetic processes require the involvement of the deep continental lithosphere, including subcontinental mantle and the lower crust. This can be as a source region for processes such as partial melting of mafic-ultramafic rocks and subsequent differentiation (e.g., Jagoutz and Klein, 2018 and reference therein) or as a region where primary magmas induce local melting of crustal material followed by assimilation and extensive mixing, i.e., the MASH zone (Hildreth \& Moorbath 1988). 
Favourable conditions for magma storage in the deeper parts of the crust, as for example in a MASH zone (hypothesis iii), could result in homogenization of discrete magma batches, obscuring any variability inherited after extraction from mantle (e.g. Hildreth and Moorbath 1988). Furthermore, hybridization in the lower crust would not only mask the primary isotopic heterogeneity but would also contribute to crustal isotopic signature (e.g. Lackey et al. 2008). However, if petrogenetic processes occur at still deeper levels where differentiation dominates over hybridization in the crust (hypotheses i and ii), the "crustal signature" of the magmas might be derived from the subducted slab and/or through metasomatism of the lithospheric mantle (e.g. Jagoutz and Klein 2018 and references therein). In such a situation, the magmas might then experience a short residence time in the lower crust or pass directly through it to shallower levels without crustal-scale homogenization of their isotopic systems.

A magmatic arc where two contrasting hypotheses on the formation of large volumes of tonalitic rocks have been proposed is the Famatinian Cordilleran-type arc in the Sierras Pampeanas, NW Argentina $\left(24^{\circ}-28^{\circ} \mathrm{S}\right)$. The generation of tonalites was related to either partial melting of a Proterozoic lithospheric crust-mantle section (e.g. Pankhurst et al. 2000; Dahlquist et al. 2008, 2013; Grosse et al. 2011; Rapela et al. 2018) or interaction between mafic magmas and supracrustal sedimentary rocks in the crust (Otamendi et al. 2012; Ducea et al. 2015). The aim of this paper is to review the magma source problem in this arc focusing mainly on $\mathrm{O}$ - and $\mathrm{H}$-isotope studies combined with radiogenic isotope data $(\mathrm{Sr}$ and $\mathrm{Nd})$ in the same rock set, which can provide valuable insights into this issue. Additionally, the $\mathrm{O}$ isotope composition of zircons of the Famatinian arc from the same study area reported by Rapela et al. (2018), which give information about the deeper source region, is compared with our $\mathrm{O}$ analyses of whole rocks that record the last stages of the magmatic system. We focus on tonalite-granodiorite genesis but also 
consider the more mafic types, and explore the possibility of a genetic link between intermediate rocks and those of felsic composition (mostly monzogranite). Source region(s), melting depth(s), and the architecture of the Famatinian continental arc are also discussed, integrating field relationships, petrology, whole-rock geochemistry and whole-rock $\mathrm{O}, \mathrm{H}, \mathrm{Sr}$ and $\mathrm{Nd}$ isotope data.

\section{The Famatinian Orogeny}

The Famatinian orogeny was a subduction-related accretionary orogeny that occurred in the Ordovician along the proto-Andean margin of Gondwana from Patagonia to Venezuela (Cawood et al. 2009). In the Sierras Pampeanas, it started with extension and marine sedimentation of the margin, followed by tectonic inversion and the setting up of a Cordilleran-type magmatic (I-type) arc that was coeval with shortening over a very short period of time of ca. 5 my, (e.g., Dahlquist et al. 2008; Cristofolini et al., 2012; Ducea et al., 2017; Rapela et al. 2018; Weinberg et al. 2018). Arc magmatism was largely coeval with the development of crustal thickening and hightemperature-low-pressure metamorphism resulting from advective heat at ca. $800^{\circ} \mathrm{C}$ and $7 \mathrm{kbar}$ (Dahlquist et al. 2005; Murra and Baldo 2006; Gallien et al. 2010, 2012; Tibaldi et al. 2013; Larrovere et al., 2019).

Ordovician magmatism was long ago recognized in the Sierras Pampeanas of NW Argentina (e.g. Toselli 1992, Rapela et al. 1992, Bahlburg and Hervé 1997). Pankhurst et al. (2000) distinguished three distinct plutonic associations between latitudes $27^{\circ} 30^{\prime}$ and $31^{\circ} 30^{\prime} \mathrm{S}: 1$ ) voluminous metaluminous intrusions of gabbro to monzogranite with largely dominant tonalite and granodiorite. This association is exposed at different crustal paleo-depths over a length of ca. $750 \mathrm{~km}$ in the Sierras Pampeanas (Fig. 1); 2) more restricted but still voluminous peraluminous granites, and 3) minor tonalite-trondhjemite-granodiorite (TTG) type rocks in the Eastern 
Sierras Pampeanas. More recently Rapela et al. (2018) divided the Famatinian orogenic belt into four domains (Western, Central, Eastern and Foreland) that show differences in the type of magmatism, metamorphism and geodynamic evolution: we focus here on the Central Domain, where a ca 470 Ma Cordilleran-type magmatic arc is exposed through an almost continuous crustal section up to the Ordovician paleosurface (Fig. 1).

\section{The Cordilleran-type magmatic arc of the Famatinian Central Domain}

Ordovician magmatism took place between ca. 490 and 460 Ma (Rapela et al. 2018). However, the Cordilleran-type magmatic arc long recognized in the Central Domain was emplaced within ca. $10 \mathrm{Myr}$ or less between ca. 468 and $478 \mathrm{Ma}$ and is a case study of a magmatic flare-up (Ducea et al., 2017; Rapela et al. 2018). A possible model for magma formation involves foundering of the subcontinental pyroxenite mantle and upwelling mantle wedge peridotite (Alasino et al. 2016). Because of almost vertical pre-Triassic tilting of crustal blocks, a continuous crustal section of the arc from a depth of ca. 7 kbar to the paleosurface is exposed that can be divided into distinct depth levels (Fig. 1).

The deeper crustal level is exposed in the Sierra de Valle Fértil (area 1 in Fig. 1) corresponding to paleo-depths of between 15 and $25 \mathrm{~km}$ (Otamendi et al. 2012) and is assumed to be the uppermost lower crust (Otamendi et al. 2009; Tibaldi et al. 2013; and this work). Tonalite and diorite bodies dominate from ca. 20 to $25 \mathrm{~km}$ with gabbro and gabbro cumulates increasing downward. Host rocks attained medium-pressure upper amphibolite to granulite facies conditions (up to 7 kbar; Otamendi et al. 2012) and mainly consist of metapelites with minor marble and calc-silicate rocks of Cambrian age (Collo et al. 2009; Cristofolini et al. 2012; Rapela 
et al. 2016). Migmatites are found as septa between igneous sheets and as partially assimilated blocks in tonalite (Otamendi et al. 2012).

At mid-crustal levels (about $15 \mathrm{~km}$ depth) there is evidence of large-scale interaction between partially molten country rocks and tonalitic magmas. Good exposures of this are found in the westernmost Sierra de Famatina, northeastern Cerro Asperecito and Cerro Toro near Villa Unión, and in the southwestern Sierra de Velasco (areas 2 and 3 in Fig. 1, e.g. Saavedra et al. 1992; Alasino et al. 2014; Bellos et al. 2015). At these localities, there are steeply dipping N-Strending sheets of tonalite and less abundant granodiorite with scarce gabbro and maficultramafic cumulates. Host rocks are high-grade metasedimentary rocks (ca. 4-5 kbar; Rossi \& Toselli 2005; Alasino et al. 2014). Water-fluxed melting was invoked by Alasino et al. (2014) to explain the high degree of melting in the host rocks in the regional thermal aureoles. Hybrid granitoids were formed by variable mixing of anatectic leucogranite with tonalite at magma chamber margins (Alasino et al. 2014).

A still shallower section, between 10 and $8 \mathrm{~km}$ depth - upper crust, is preserved in the Sierra de Los Llanos and the central part of the Sierra de Famatina (areas 4 and 5 in Fig. 1). Here there are large elongated subvertical bodies consisting of granodiorite to biotite monzogranite and local gabbro, tonalite and leucogranite. Host rocks are medium- to low-grade metasedimentary rocks of the same age as the deeper ones (Pankhurst et al. 2000; Rapela et al. 2016). Local autochthonous to parachthonous bodies of peraluminous two-mica cordierite monzogranites are formed by partial melting of metasedimentary rocks (Pankhurst et al. 2000) (Fig. 1).

The uppermost magmatic arc, corresponding to the subvolcanic environment and the paleosurface is preserved in the central and eastern part of Sierra de Famatina and in its northward continuation into the Sierra de Narváez -Las Planchadas (areas 5 and 6, Fig. 1). This 
consists mainly of submarine volcaniclastic and rhyolites, scarce basalts and a few granitoid plutons (for a review see Rapela et al. 2018 and references therein).

Crystallization ages (U-Pb zircon) of Famatinian igneous rocks range from ca 468 to ca 482 Ma (90\% of the samples) (Table 1 and Rapela et al., 2018 and references therein) distributed in two peaks (c. 470 and c. $480 \mathrm{Ma}$ ). In fact, the Cordilleran-type magmatic arc (best dated in the Sierra de Valle Fértil) was emplaced in a short interval of ca. 5 Ma between 467 and 472 Ma (U$\mathrm{Pb}$ TIMS; Ducea et al. 2017). The older magmatism corresponding to the $480 \mathrm{Ma}$ age peak is masked by the ca. $470 \mathrm{Ma}$ one and is as yet poorly defined (e.g. Pankhurst et al. 2000; Dahlquist et al. 2013). Additionally, on the basis of field relations together with geochemical and isotopic data, Alasino et al. (2016) recognised two temporal suites for the mafic rocks: an older intrusive suite (> $480 \mathrm{Ma})$ and a younger suite, typically displaying subduction-related geochemical signatures, coeval with the magmatic flare-up at ca. 470 Ma.

Based on field evidence, chemistry and geochronology, five major igneous units form the $c$. $470 \mathrm{Ma}$ Cordilleran-type magmatic arc: (i) an older gabbro suite (mostly coronitic metagabbros and gabbros); (ii) a subsequent suite of gabbros and diorites; (iii) voluminous tonalites to monzogranites coeval with the latter suite (or volcanic equivalents); (iv) granitoids with a crustal melt component including (iv.1) anatectic leucogranitoids (small bodies and veins) and (iv.2) two-mica ( \pm cordierite) granitic bodies; and (v) hybrid rocks resulting from local mixing of tonalite with crustal melts. An unexposed basement of Mesoproterozoic age (Casquet et al. 2012) probably underlies the magmatic arc (Rapela et al. 2018). The root of the magmatic arc attained minimum $12 \mathrm{kbar}$, depths of ca. $40-45 \mathrm{~km}$ (Casquet et al. 2012), but no xenoliths of mantle or lower-crust have been recorded so far. 


\section{Sampling, description and analytical methods}

Rocks analysed for whole-rock $\mathrm{O}$ isotope composition were: one metagabbro, two gabbronorite and eight gabbros of the older suite (i); four $\mathrm{Bt} \pm \mathrm{Hbl}$ tonalite-granodiorite samples, two Bt-rich granodiorite-monzogranite samples, two rhyolites and one leucogranite (suite iii); one hybrid rock with migmatitic texture collected near the migmatitic host rock (sample FAM332) (suite v) and two migmatites, one gneiss and three two-mica ( \pm cordierite) monzogranites of suite (iv) (Tables 1 and 2). The samples were collected from bottom to top of the exposed crustal section of the Central Domain (see above and Table 1). Some of these samples were also analyzed for $\mathrm{H}$ (see Table 2). Additionally, the dataset includes $\mathrm{O}$ analyses of one metagabbro and one gabbro of the older suite (i) with evidence of weak alteration (sample ASP221); two diorites of the younger suite (ii); one $\mathrm{Bt} \pm \mathrm{Hbl}$ tonalite of suite (iii); one hybrid of granitic appearance (sample FAM7086) (suite v) and one migmatite and one gneiss previously reported by Alasino et al. (2016) (Tables 1 and 2). We have included for comparison two samples from the Sierra de Ancasti in the Eastern Famatinian Domain (Rapela et al., 2018 and references therein): one Pl-rich tonalite (ANC11030a) and one monzogranite (ANC11022) (Tables 1 and 2). They were almost coeval with the Cordilleran-arc of the Central Domain but emplaced away from the trench (at least $300 \mathrm{~km}$ ) (Dahlquist et al., 2012).

Oxygen and hydrogen isotope analyses of 15 petrographically fresh rocks were analysed at the Scottish Universities Environmental Research Centre. O analyses were performed by a laser fluorination procedure, involving total sample reaction with excess $\mathrm{ClF}_{3}$ using a $\mathrm{CO}_{2}$ laser at temperatures in excess of $1500{ }^{\circ} \mathrm{C}$ (Sharp 1990). Samples were evacuated overnight, and prefluorinated for 90 seconds prior to fluorination. All fluorinations resulted in $100 \%$ release of $\mathrm{O}_{2}$ from the silicate lattice. This $\mathrm{O}_{2}$ was converted to $\mathrm{CO}_{2}$ by reaction with hot graphite, and 
analysed by a VG SIRA II spectrometer. Results are reported in standard notation $\left(\delta^{18} \mathrm{O}\right)$ as per mil (\%o) deviations from Vienna Standard Mean Ocean Water (V-SMOW). 2 standards were run with each whole rock analyses, giving an overall error of reproducibility typically less than $\pm 0.3 \%$ during analyses, with international standard UWG-2 giving an average value of $5.7 \pm$ $0.1 \%$ during these analyses. Hydrogen analysis was done by in vacuo bulk heating of around $100 \mathrm{mg}$ of whole rock analysed using the method of Donnelly et al. (2001) and a VG- Micromass Optima mass spectrometer. Samples were heated to $>1000^{\circ} \mathrm{C}$ by induction furnace to release included fluids. Results are reported in standard notation $(\delta \mathrm{D})$. Additionally, $\mathrm{O}$ isotope analyses of 15 petrographically fresh rocks and one gabbro with evidence of weak alteration (sample VCA7037) were carried out at the Servicio General de Análisis de Isótopos Estables (University of Salamanca, Spain) on whole-rock powders by laser fluorination (Clayton \& Mayeda 1963), employing a Synrad $25 \mathrm{~W} \mathrm{CO}_{2}$ laser (Sharp 1990) and $\mathrm{ClF}_{3}$ as reagent (e.g. Borthwick \& Harmon 1982). Isotope ratios were measured on a VG-Isotech SIRA-II dual-inlet mass spectrometer. Both internal and international reference standards (NBS-28, NBS-30) were run to check accuracy and precision. Results are reported in $\delta^{18} \mathrm{O}$ notation relative to $\mathrm{V}$-SMOW (Vienna Standard Mean Ocean Water), using a $\delta^{18} \mathrm{O}$ value of $9.6 \%$ for NBS-28 (quartz) for the mass spectrometer calibration (Table 2). Long-term reproducibility for repeated determination of reference samples was better than $\pm 0.2 \%$ o $(1 \sigma)$. Finally, D/H ratios of five samples from the last data set were measured on whole-rock powders using the technique of Godfrey (1962). Results are reported in standard notation ( $\delta D)$ (Table 2).

New $\mathrm{Sr}$ and/or Nd isotope analyses for six samples (CTO30003, SFV40039, FAM40025, FAM303, ANC11030a and ANC11022) were carried out at the Geochronology and Isotope Geochemistry Center, Complutense University (Madrid, Spain) using an automated 
multicollector VG® SECTOR 54 mass spectrometer (Table 3). Errors are quoted throughout as two standard deviations from measured or calculated values. Analytical uncertainties are estimated to be $0.006 \%$ for ${ }^{143} \mathrm{Nd} /{ }^{144} \mathrm{Nd}$ and $0.1 \%{ }^{147} \mathrm{Sm} /{ }^{144} \mathrm{Nd}$, the latter parameter determined by isotope dilution. Fifty-six analyses of La Jolla Nd-standard over one year gave a mean ${ }^{143} \mathrm{Nd} /{ }^{144} \mathrm{Nd}$ ratio of $0.511846 \pm 0.00003$. These samples were analysed for whole-rock major oxides and trace elements using inductively coupled plasma-mass spectrometry (ICP-MS) at Activation Laboratories, Ancaster, Ontario, Canada, under the "4LithoResearch" package, following the procedure described at http://www.actlabs.com (supplementary data). Additionally, we have taken into consideration the $\mathrm{Sr}$ and $\mathrm{Nd}$ isotope analyses reported by Dahlquist et al. (2012), Rapela et al. (2018) and Alasino $(2014,2016)$ for the remaining samples in table 2 (all recalculated to $470 \mathrm{Ma}$ ) (Table 3 ).

A database of ca. 100 already reported geochemical analyses from the studied zone are included in figures $3 \mathrm{~b}, 4 \mathrm{a}$ and $4 \mathrm{~b}$ for the petrogenetic discussion (see supplementary data).

\section{Isotope analysis}

\section{5.a. $\mathrm{O}$ and $\mathrm{H}$ data}

Four main groups of rocks from the Central Domain are considered here on the basis of the $\mathrm{O}$ isotope composition (Table 2):

G1 consists of one gabbronorite from the deepest exposed crustal level and one granulite facies coronitic troctolitic gabbro from the intermediate level. They are the most juvenile rocks in terms of the $\mathrm{O}$-isotope composition, with low $\delta^{18} \mathrm{O}$ values of around $+5.3 \%$ (Table 2), i.e., mantle-like values (ca. $+5.5 \%$; e.g. Hoefs 2009 ) 
$\mathrm{G} 2$ comprises a variety of rocks with $\delta^{18} \mathrm{O}$ values ranges from +6.2 to $+9.5 \%$. This group includes: one coronitic gabbro, and 13 gabbro-diorite samples from the deepest and intermediate depths with $\delta^{18} \mathrm{O}$ values between +6.6 and $+9.4 \%$; five $\mathrm{Bt} \pm \mathrm{Hbl}$ tonalite-granodiorite samples from the three deeper levels with $\delta^{18} \mathrm{O}$ values from +7.8 to $+9.3 \%$; two Bt-rich granodioritemonzogranite samples, one leucogranite and three rhyolites (one with a superimposed low-grade metamorphism) are from the uppermost crustal section with $\delta^{18} \mathrm{O}$ values from +6.2 to $+9.5 \%$ (Table 2).

The G3 group consists of two hybrid granitoids formed by variable mixing of the tonalitic magma with partially molten metasedimentary rocks in the regional thermal aureole, with $\delta^{18} \mathrm{O}$ values of $+8.7 \%$ for FAM7086 and $+9.9 \%$ for FAM332 (Table 2).

The G4 group consists of five metasedimentary rocks (migmatite and gneiss) from the deepest and intermediate depth and three peraluminous granites from intermediate to shallow depth that show the highest $\delta^{18} \mathrm{O}$ values between +10.2 and $+14.7 \%$ (Table 2).

Hydrogen isotope analysis of arc samples yielded: a value of $-113 \%$ from one G1 gabbro; $\delta \mathrm{D}$ values between -58 and $-101 \%$ from the $\mathrm{G} 2$ including two gabbros, two diorites, one tonalite, two granodiorites, one leucogranite and two rhyolites; one value of $\delta \mathrm{D}=-93$ from a hybrid of the G3; and values between -69 and $-124 \%$ from five metasedimentary rocks and three Crd-granites of the G4 (Table 2).

Rocks of the Eastern Famatinian Domain similar to the G2 group yielded $\delta^{18} \mathrm{O}$ values of +9.2 $\%$ o for the tonalite (ANC11030a) and +8.7 \%o for the monzogranite (ANC11022). The corresponding $\delta \mathrm{D}$ values are $-99 \%$ and $-72 \%$, respectively (Table 2 ).

\section{5.b. Sr and Nd data}


In terms of the $\mathrm{Sr}$ and $\mathrm{Nd}$ isotope composition (calculated at $470 \mathrm{Ma}$; Table 3) the G1 gabbros yield $\varepsilon N d_{t}$ values close to -2 and relatively radiogenic ${ }^{87} \mathrm{Sr} /{ }^{86} \mathrm{Sr}$ ratios of about 0.7085 . The largest G2 group yielded values of $\varepsilon \mathrm{Nd}_{\mathrm{t}}$ between -0.9 and -5.8 and ${ }^{87} \mathrm{Sr} /{ }^{86} \mathrm{Sr}_{\mathrm{t}}$ values between 0.7053 and 0.7113 with most of the samples falling within the ranges -3 to -5 and 0.7070 to 0.7090, respectively. The G3 hybrid granitoids show values of $\varepsilon \mathrm{Nd}_{t}$ (ca. -6.1 ) intermediate between those of G2 and G4, with ${ }^{87} \mathrm{Sr} /{ }^{86} \mathrm{Srt}_{\mathrm{t}}$ values of 0.7084 for FAM7086 and 0.7125 for FAM332. The G4 group yields $\varepsilon \mathrm{Nd}_{\mathrm{t}}$ values between -5.4 and -8.2 and ${ }^{87} \mathrm{Sr} /{ }^{86} \mathrm{Sr}_{\mathrm{t}} \geq 0.7102$.

Tonalite and monzogranite of the Eastern Famatinian Domain yielded $\varepsilon N d_{t}$ values of -4.3 and -3.1 and ${ }^{87} \mathrm{Sr} /{ }^{86} \mathrm{Sr}_{\mathrm{t}}$ values of 0.7086 and 0.7056 , respectively (Table 3 ).

\section{Discussion}

\section{6.a. O-Sr-Nd isotopic composition of the Famatinian arc magmas}

Oxygen isotope analyses were conducted on fresh rocks that do not exhibit significant postmagmatic alteration, except for two gabbro samples from Cerro Asperecito (ASP221 and VCA7037). There is no apparent correlation between the ${ }^{87} \mathrm{Sr} /{ }^{86} \mathrm{Sr}_{\mathrm{t}}$ and $\delta^{18} \mathrm{O}$ values in the G2 group (Fig. 2a). The G1 gabbros have the lowest $\delta^{18} \mathrm{O}$ values but $\mathrm{Sr}$ isotope values similar to the G2 gabbros and tonalites-granodiorites, which strengthens this apparent lack of correlation between the two isotope systems. Migmatites form a group apart with $\delta^{18} \mathrm{O}$ values typical of metasedimentary rocks (e.g. Hoefs 2009). A G2 gabbro that plots between the G2 rocks and the G4 host migmatites but does not show significant bulk contamination with crustal material in its composition suggests some fluid-rock interaction (see section 6.d). The G3 hybrid granitoids show much scatter: FAM7086 overlaps the field defined by G2 samples whereas FAM332 plots between the G2 rocks and the G4 host migmatites. A binary mixing model based on the ${ }^{87} \mathrm{Sr} /{ }^{86} \mathrm{Sr} t$ 
ratios is consistent with variable crustal contribution (Table 4): the calculated percentages of assimilated metasedimentary rocks (and/or derived melts) are 6\% and 39\% for tonalites FAM7086 and FAM332, respectively. Mixing rates based on O-isotope data show similar values of $5 \%$ and $40 \%$, respectively (Table 4 ).

Average $\delta^{18} \mathrm{O}$ values of G2 and G4 igneous zircon of Famatinian age (c. 470 Ma; Rapela et al. 2018) and the corresponding whole-rock values correlate well with $\Delta \delta^{18} \mathrm{O}_{\mathrm{wR}-\mathrm{Zr}} \leq 2.4 \%$ (Fig. $2 b$ ). This suggests that the whole-rock oxygen isotope composition is that of the magma and that a significant interaction with low $\delta^{18} \mathrm{O}$ meteoric waters after crystallization did not play a role (see section 6.d). Some felsic rocks are exceptions, such as rhyolite CHA3008 which shows the largest $\Delta \delta^{18} \mathrm{O}_{\mathrm{WR}-\mathrm{Zr}}\left(\sim 4 \%\right.$ \%). The low ${ }^{87} \mathrm{Sr} /{ }^{86} \mathrm{Sr}_{\mathrm{t}}$ ratio $(0.7059)$, high $\varepsilon \mathrm{Nd}_{\mathrm{t}}(-0.9)$, and low $\delta^{18} \mathrm{O} \mathrm{Zr}$ $(+4.9)$ of this rock points to some disequilibrium between zircon and the whole rock that did not affect the other isotope systematics. This implies that the rhyolite composition was not affected by bulk assimilation of supracrustal rocks but reflects either original magmatic differences or the effect of metamorphic fluids (see section 6.d).

Except for a potential negative correlation of the whole-rock O-isotope composition with the ${ }^{147} \mathrm{Nd} /{ }^{143} \mathrm{Nd}_{\mathrm{t}}$ ratio for $\mathrm{G} 1$ and $\mathrm{G} 2$ mafic rocks discussed in section $6 . \mathrm{b}$, the remaining rocks of the G2 group (tonalites and other granitoids and volcanics) show that the isotope systematics $(\mathrm{O}, \mathrm{Sr}$ and $\mathrm{Nd}$ ) are largely uncoupled as was noted by Rapela et al. (2018) using O in zircon (Figs. 2a and 2c). Zircons analysed by Rapela et al. (2018) exhibit $\mathrm{O}$ isotope values within the same range as both the gabbros $\left(\delta^{18} \mathrm{O}=+6.5\right.$ to $\left.+8.1 \%\right)$ and the tonalite-granodiorites $\left(\delta^{18} \mathrm{O}=+6.7\right.$ to +9.5 $\%$ ). Moreover the range of zircon O-isotope values overlaps with the whole-rock $\mathrm{O}$ isotope values for the same rock types of the $\mathrm{G} 2$ group $\left(\delta^{18} \mathrm{O}=+6.6\right.$ to $+9.4 \%$ (Table 2$)$. This finding strengthens the idea that the oxygen isotopic composition did not change significantly after 
zircon crystallization $\left(\mathrm{T} \sim 850{ }^{\circ} \mathrm{C}\right)$ and that isotopic homogenization was not a major process operating on a regional scale.

\section{6.b. Origin of the enriched sub-arc mantle in the Famatinian arc}

Unlike mid-ocean ridge basalts (MORBs) that derive from a fairly uniform melt-depleted upper mantle $\left({ }^{87} \mathrm{Sr} /{ }^{86} \mathrm{Sr}_{\mathrm{t}} \sim 0.703, \varepsilon \mathrm{Nd}_{\mathrm{t}} \sim+8\right.$ and $\delta^{18} \mathrm{O} \sim+5.7 \%$; Saunders et al. 1998; Harmon $\&$ Hoefs 1995), the Famatinian G1 and G2 gabbros-diorites are isotopically evolved in terms of Sr and Nd. They show average values of ${ }^{87} \mathrm{Sr} /{ }^{86} \mathrm{Sr}_{\mathrm{t}}=0.7085, \varepsilon \mathrm{Nd}_{\mathrm{t}}=-2$ and $\delta^{18} \mathrm{O}=+5.3 \%$ \% $(\mathrm{G} 1 ; \mathrm{n}$ $=2)$, and ${ }^{87} \mathrm{Sr} /{ }^{86} \mathrm{Sr}_{\mathrm{t}}=0.7081, \varepsilon \mathrm{Nd}_{\mathrm{t}}=-3.7$ and $\delta^{18} \mathrm{O}=+7.6(\mathrm{G} 2 ; \mathrm{n}=11$, excluding samples ASP221, VCA7037 and SVF571 that probably underwent some modification in the crust -see below). The high initial ${ }^{87} \mathrm{Sr} /{ }^{86} \mathrm{Sr}$ ratios and low ${ }^{143} \mathrm{Nd} /{ }^{144} \mathrm{Nd}$ ratio of the two G1 meta-gabbro, with typical $\delta^{18} \mathrm{O}$ mantle values suggest that these rocks acquired their isotope "crustal" characteristics at the source in the mantle. In the ${ }^{87} \mathrm{Sr}^{86} \mathrm{Sr}_{\mathrm{t}}$ versus $\delta^{18} \mathrm{O}$ plot, the isotope compositions of the G1 mafic rocks could result from assimilation of less than $5 \%$ of a subduction-derived crustal component (Fig. 2a) (e.g., James 1981; Davidson et al. 2005). For the G2 mafic rocks, however, the primary magma would require approximately $40 \%$ of crustal material with a $\delta^{18} \mathrm{O}$ value of $+12.6 \%$ to reproduce the $\mathrm{O}$-isotope data, which is inconsistent with the major element compositions (Fig. 2a). In this case, the contamination of mafic magmas by the host metasedimentary rocks played a minor role (e.g., Pankhurst et al. 2000; Walker Jr. et al. 2015; Alasino et al. 2016).

In continental arcs the isotope signature of enriched-mantle derived magmas is difficult to distinguish from that resulting from crustal assimilation of depleted mantle magmas. The latter interpretation commonly prevails in relation to continental arc magmatism (e.g. Bindeman 2008 
and reference therein). However, the distinction remains controversial inasmuch as the root of the arcs is inaccessible and deep-seated igneous rocks with xenoliths are missing. This has been the case of the Famatinian arc, where assimilation of continental crust has been invoked (e.g. Otamendi et al. 2012; Walker et al. 2015). Walker et al. (2015) observed isotope decoupling as a product of prolonged but punctuated MASH processes in the lower crust of the arc. This view has recently been challenged by petrogenetic models involving enriched sub-arc mantle (Alasino et al. 2016; Rapela et al. 2018). Evidence for high $\delta^{18} \mathrm{O}$ sources in the sub-arc mantle has been provided in some cases elsewhere. Eiler et al. (1998) reported $\delta^{18} \mathrm{O}$ values of up to $+12 \%$ in xenoliths from Papua-New Guinea, which they attributed to metasomatism of the sub-arc mantle by $\delta^{18} \mathrm{O}$-enriched fluids. Dorendorf et al. (2000) reported heavy O-isotope compositions in olivine and pyroxene from the Klyuchevskoy volcano, Kamchatka (Russia) implying magma with mean $\delta^{18} \mathrm{O}$ values between +6.2 and $+7.5 \%$ : again slab-released hydrous melts with high $\delta^{18} \mathrm{O}$ values were invoked. Liu et al. (2014) studied olivine from mantle xenoliths in basalts from South Tibet and concluded that magmas were derived from a sub-arc metasomatized mantle source with $\delta^{18} \mathrm{O}$ values of $+8.03 \pm 0.28 \%$. Slab-derived fluid/melts with high $\delta^{18} \mathrm{O}$ values are to be expected in subduction zones because weathered and hydrothermally altered upper oceanic crust has $\delta^{18} \mathrm{O}$ values between +7 and $+15 \%$ (review in Bindeman 2005).

Based on chemical and isotopic compositions of the mafic rocks exposed in both the forearc region (in the westernmost Sierras Pampeanas, see Ramacciotti et al. 2019) and the arc region studied here, garnet-pyroxenite (sensu lato) and peridotite were proposed as the sources of the mafic magmas in the arc (Alasino et al. 2016). These authors suggested that mixing between a subordinate primitive magma and an 'enriched' lithospheric mantle could explain both the range of $\varepsilon N d_{t}$ values (from +4.8 to -6.0 ) and the $\delta^{18} \mathrm{O}$ composition (from +5.3 to $+9 \%$ ) in the mafic 
samples (see compilation data in Alasino et al. 2016). The good negative correlation between $\delta^{18} \mathrm{O}$ and ${ }^{143} \mathrm{Nd} /{ }^{144} \mathrm{Nd}(\mathrm{r}=0.7$; Fig. 3a) for our arc mafic rocks suggests that both were inherited from the source and could be acquired in a mixing process between the enriched lithospheric mantle and the depleted mantle. This interpretation is strengthened in a ${ }^{143} \mathrm{Nd} /{ }^{144} \mathrm{Nd} \mathrm{vs}$. La/Sm plot (Fig. 3b), which shows the composition of melts from heterogeneous mantle sources (Stracke 2012). The mafic samples of the orogen scatter between an isotopically enriched source (subcontinental lithospheric mantle?) with an estimated value of ${ }^{143} \mathrm{Nd} /{ }^{144} \mathrm{Nd} \sim 0.5122$ and depleted peridotite, i.e., the source of MORB-type magmas (Fig. 3b). This suggests that mafic melts can be extracted from a large range of depths with little melt mixing between these two protoliths, due to either the absence of a thick lithosphere or high excess mantle temperatures (e.g. Stracke 2012), producing the heterogeneity and the enrichment in their isotopic compositions.

In summary, we suggest that the sub-arc mantle was dominantly enriched and isotopically heterogeneous. Magmas produced by the melting of such metasomatized mantle (e.g., eclogite) may explain the characteristic geochemical signature of arc magmas formed in subduction zones (Rumble et al. 2003; Gonzaga et al. 2010; Chapman et al. 2017).

\section{6.c. Origin of silicic magmas}

There is no significant major difference in isotope composition between G2 mafic rocks thought to have been derived mostly from an enriched lithospheric mantle (av. $\delta^{18} \mathrm{O}=+8 \pm 0.8$ $\%{ }^{87} \mathrm{Sr} /{ }^{86} \mathrm{Sr}_{\mathrm{t}}=0.7082 \pm 0.0016$ and $\left.\varepsilon \mathrm{Nd}_{\mathrm{t}}=-4 \pm 1.1 ; \mathrm{n}=14\right)$ and tonalite-granodiorite rocks (av. $\delta^{18} \mathrm{O}=+8.7 \pm 0.5 \%,{ }^{87} \mathrm{Sr} /{ }^{86} \mathrm{Sr}_{\mathrm{t}}=0.7088 \pm 0.0001$ and $\varepsilon \mathrm{Nd}_{\mathrm{t}}=-4.5 \pm 0.6 ; \mathrm{n}=5$ ). This observation also applies to the Eastern Famatinian Domain, implying not only similar magmatic evolution in 
both regions at approximately $470 \mathrm{Ma}$ but also a ubiquitous occurrence of the source in the orogen (Fig. 2c). Therefore, an old lithospheric (evolved) mantle source is invoked rather than depleted mantle with assimilation of crustal material. The latter would require that each batch of mafic magma had assimilated just the right amount of extremely heterogeneous crustal material to generate the same range of isotope compositions over a wide area (see also Rapela et al. 2018).

However there is field and geochemical evidence that G2 intermediate magmas were modified to some extent by contamination with supracrustal rocks (e.g. Otamendi et al. 2012; Alasino et al. 2014; Walker Jr. et al. 2015). Contamination with host rocks is recognized in the ${ }^{87} \mathrm{Sr} /{ }^{86} \mathrm{Srt}$ vs. $\mathrm{K}_{2} \mathrm{O}$ plot as a significant increase of the ${ }^{87} \mathrm{Sr} /{ }^{86} \mathrm{Sr}_{\mathrm{t}}$ (up to ca. 0.720) along with increasing $\mathrm{K}_{2} \mathrm{O}$ content (Fig. 4a). This trend is shown by some tonalites (5 out of 32 samples) found in the Sierra de Valle Fértil and the western Sierra de Famatina. The hybrid FAM7086, with an assimilation of approximately $6 \%$ of wall rock, remains quite uniformly within the G2 tonalite group, whereas the FAM332 with an assimilation rate near 40\% follows the trend of contaminated rocks. The remarkable increase in the ${ }^{87} \mathrm{Sr} /{ }^{86} \mathrm{Sr}_{\mathrm{r}}$ ratio of some tonalites from the Sierra de Valle Fértil (up to ca. 0.715), departing from the main differentiation trend in a plot against Sr concentration (Fig. 4b), strengthens this interpretation.

If an initial Sr-isotope value of 0.7073 (the mean for the three most primitive G2 tonalites in the dataset) is taken as the starting magma composition, and the more radiogenic composition of the metasedimentary rock $(0.7216)$ is regarded as the contaminant, the rest of the G2 tonalites would require to assimilate up to $40 \%$ (in most cases $10-15 \%$ ) pre-existing crust to reproduce the $\mathrm{Sr}_{\mathrm{t}}$ value (Fig. $4 \mathrm{~b}$ and Table 4). Magma mixing ratios based on O-isotope data yield similar values (Table 4). If the lightest $\delta^{18} \mathrm{O}$ value of $+7.8 \%$ from the $\mathrm{G} 2$ tonalites is taken as typical of 
the starting magma and the mean of the five G4 rocks as representing the crustal contaminant $\left(\delta^{18} \mathrm{O}=+12.6 \%\right.$ ), $25 \%$ contamination would be required to raise the $\delta^{18} \mathrm{O}$ of the magma by $1 \%$.

Crustal assimilation is only recorded in tonalite-granodiorite, not in granite-rhyolite samples. In fact, the latter show a decrease of the ${ }^{87} \mathrm{Sr} /{ }^{86} \mathrm{Sr}_{\mathrm{t}}$ ratio down to ca. 0.7059, with a complementary decrease of $\mathrm{Sr}$ content, suggesting that some of the felsic magmas evolved independently of the tonalite-granodiorite magmas, with a trend towards more juvenile isotopic composition (Fig. 4b). Likewise, in the ${ }^{147} \mathrm{Nd} /{ }^{143} \mathrm{Ndt}$ versus $\delta^{18} \mathrm{O}$ plot the felsic rocks record values close to the most primitive mafic rocks (Fig. 2c).

\section{6.d. Crustal fluids in the Famatinian arc}

The $\delta^{18} \mathrm{O}$ vs $\delta \mathrm{D}$ plot (Fig. 5) shows that both igneous and sedimentary rocks display a wide range of $\delta \mathrm{D}$ values from -58 to $-124 \%$, with a restricted range of $\delta^{18} \mathrm{O}$ values for the Central Domain. Part of the G4 rocks (two migmatites, one gneiss and two Crd-granites with values $\delta^{18} \mathrm{O}$ $\geq+10.5 \%$ and $\delta \mathrm{D} \sim-73 \%$ ) plot mostly outside of the metamorphic water box and to the right of the magmatic water box (Fig. 5). Moreover, some G4 samples yield low $\delta \mathrm{D}$ values (down to $124 \%$ ) likewise resulting from the same interaction with meteoric fluids. A group of samples of the G2 (mostly gabbro-diorite and monzogranite-rhyolite) with values of $\delta^{18} \mathrm{O}=+6.2$ to $+8.1 \%$ and $\delta \mathrm{D}=-68$ to $-79 \%$ ) are within the igneous box (Fig. 5). The rest of the G2 rocks and the G1 gabbro plot below the igneous box, suggesting some exchange with meteoric fluids small enough to affect the isotope composition of $\mathrm{H}$ but not that of $\mathrm{O}$, thus implying low fluid/rock ratios. Moreover, the effect of metamorphic fluids on the isotope composition seems to be minor as most samples plot outside the corresponding box and a clear trend is not visible. The G3 sample 
(a hybrid rock with approximately $40 \%$ contamination) falls consistently into the field of the metamorphic rock but close to igneous rocks.

\section{Conclusions}

The stable $(\mathrm{O}$ and $\mathrm{H})$ and radiogenic $(\mathrm{Sr}$ and $\mathrm{Nd})$ isotope data for representative whole-rock rocks from the main Famatinian arc in the Sierras Pampeanas, consisting of voluminous metaluminous gabbro to monzogranite magmas with tonalite and granodiorite dominant, preserve evidence that the sub-arc mantle was the main source region. The sub-arc mantle was isotopically heterogeneous, including an "enriched" domain $\left(\delta^{18} \mathrm{O} \sim+8 \%\right.$ ) as well as a subordinate depleted member $\left(\delta^{18} \mathrm{O} \sim+5 \%\right)$.

The diversity of magmatic isotope compositions preserved in the tonalite-granodiorite arc rocks $\left(\right.$ av. $\delta^{18} \mathrm{O}=+8.7 \pm 0.5 \%, \delta \mathrm{D}=-73 \pm 14 \% 0,{ }^{87} \mathrm{Sr} /{ }^{86} \mathrm{Sr}_{\mathrm{t}}=0.7088 \pm 0.0001$ and $\varepsilon \mathrm{Nd}_{\mathrm{t}}=-4.5$ \pm 0.6 ) shows no major difference from the isotopic composition of most of the contemporaneous mafic rocks $\left(\right.$ av. $\delta^{18} \mathrm{O}=+8 \pm 0.8 \%, \delta \mathrm{D}=-84 \pm 18 \%{ }^{87} \mathrm{Sr} /{ }^{86} \mathrm{Sr}_{\mathrm{t}}=0.7082 \pm 0.0016$ and $\varepsilon \mathrm{Nd}_{\mathrm{t}}=-$ $4 \pm 1.1$, suggesting that arc magmas acquired their "crustal" characteristics in the mantle source. The isotopic fingerprint of the tonalite-granodiorite suite acquired in the subcontinental mantle was then partially modified in the crust with the most samples explicable by $10-15 \%$ assimilation of crustal material $\left(\delta^{18} \mathrm{O}=+12.2 \pm 1.7 \%, \delta \mathrm{D}=-89 \pm 21 \% 0,{ }^{87} \mathrm{Sr} /{ }^{86} \mathrm{Sr}_{\mathrm{t}}=0.7146 \pm 0.0034\right.$ and $\left.\varepsilon N d_{t}=-6.9 \pm 0.7\right)$. The felsic magmas that reached upper crustal levels $\left(\delta^{18} \mathrm{O}=9.9 \pm 1.5 \%\right.$, $\delta \mathrm{D}$ $\left.=-76 \pm 5 \%,{ }^{87} \mathrm{Sr}^{86} \mathrm{Sr}_{\mathrm{t}}=0.7067 \pm 0.0010, \varepsilon \mathrm{Nd}_{\mathrm{t}}=-3.5 \pm 1.4\right)$ were not derived by crustal assimilation and fractionation of the intermediate contaminated magmas, but evolved from different magma batches independently of the origin of the tonalite-granodiorite. Some rocks of the orogen, both igneous (mostly gabbro and tonalite) and metamorphic underwent restricted 
interaction with meteoric fluids that did not significantly modify the $\mathrm{O}$ isotope composition but lowered whole-rock $\delta \mathrm{D}$ values.

Reported values of $\delta^{18} \mathrm{O}$ of zircon from the Famatinian arc rocks ( +6 to $+9 \%$ ) do not show differences from our whole-rock $\delta^{18} \mathrm{O}$ data, indicating that pervasive oxygen isotope exchange after zircon crystallization was not a major process in the lower crust during the magmatic flareup at $\sim 470 \mathrm{Ma}$. The Famatinian arc was built from multiple magma batches that evolved independently at variable depths suggesting that diversification processes, such as mixing and homogenization, in the continental crust play a secondary role in forming final compositional diversity in the studied arc. A representative magmatic column of the Famatinian arc is shown in figure 6.

Acknowledgements. Funds were provided by a Spanish CGL2016-76439-P grant from the MINECO (Ministry of Economy) and an Argentinean PICT 2017-0619 grant. The first author thanks Scott Paterson for thorough discussions on the geology of the Famatinian arc.

\section{References}

Alasino PH, Casquet C, Larrovere MA, Pankhurst RJ, Galindo C, Dahlquist JA, Baldo EG and Rapela CW (2014) The evolution of a mid-crustal thermal aureole at Cerro Toro, Sierra de Famatina, NW Argentina. Lithos 190/191, 154-172, doi:10.1016/j.lithos.2013.12.006.

Alasino PH, Casquet C, Pankhurst RJ, Rapela CW, Dahlquist JA, Galindo C, Larrovere MA, Recio C, Paterson SR, Colombo F and Baldo EG (2016) Mafic rocks of the Ordovician Famatinian magmatic arc (NW Argentina): new insights into the mantle contribution. Geological Society American Bulletin 128, 1105-1120, doi:10.1130/B31417.1. 
Annen C, Blundy J and Sparks R (2006) The genesis of intermediate and silicic magmas in deep crustal hot zones. Journal of Petrology 47, 505-539, doi:10.1093/petrology/egi084.

Arth JG, Barker F, Peterman ZE and Friedman I (1978) Geochemistry of the gabbro-dioritetonalite-trondhjemite suite of southern Finland and its implication for the origin of tonalitic and trondhjemitic magma. Journal of Petrology 19, pp. 289-316.

Bahlburg H \& Hervé F (1997) Geodynamic evolution and tectonostratigraphic terranes of northwestern Argentina and Northern Chile. Geological Society American Bulletin 109, 869884, doi:10.1130/0016-7606(1997)109<0869:GEATTO>2.3.CO;2

Bellos LI, Castro A, Díaz-Alvarado J and Toselli A (2015) Multi-pulse cotectic evolution and insitu fractionation of calc-alkaline tonalite-granodiorite rocks, Sierra de Velasco batholith, Famatinian belt, Argentina. Gondwana Research 27, 258-280, doi:10.1016/j.gr.2013.09.019.

Bindeman IN (2005) Oxygen isotope evidence for slab melting in modern and ancient subduction zones. Earth Planetary Science Letters 235, 480-496, doi: 10.1016/j.eps1.2005.04.014.

Bindeman IN (2008) Oxygen Isotopes in Mantle and Crustal Magmas as Revealed by Single Crystal Analysis. Reviews in Mineralogy and Geochemistry 69, 445-478, doi:0.2138/rmg.2008.69.12.

Borthwick J \& Harmon RS (1982) A note regarding $\mathrm{ClF}_{3}$ as an alternative to $\mathrm{BrF}_{5}$ for oxygen isotope analysis. Geochimica et Cosmochimica Acta 46, 1665-1668, doi:10.1016/00167037(82)90321-0.

Castro A (2014) The off-crust origin of granite batholiths. Geoscience Frontiers 5, 63-75, doi:10.1016/j.gsf.2013.06.006. 
Casquet C., Rapela CW, Pankhurst RJ, Baldo E, Galindo C., Fanning CM and Dahlquist J. (2012) Fast sediment underplating and essentially coeval juvenile magmatism in the Ordovician margin of Gondwana, Western Sierras Pampeanas, Argentina. Gondwana Research 22, 664-673, doi: 10.1016/j.gr.2012.05.001.

Cawood PE, Kröner A, Collins WJ, Kusky TM, Mooney WD and Windley BF (2009) Accretionary orogens through Earth history. Geological Society London, Special Publications no. 318, 1-36, doi:10.1144/SP318.1.

Chapman JB, Ducea MN, Kapp P, Gehrels GE and DeCelles PG (2017) Spatial and temporal radiogenic isotopic trends of magmatism in Cordilleran orogens. Gondwana Research 48, 189-204, doi: 10.1016/j.gr.2017.04.019.

Clayton RN \& Mayeda TK (1963) The use of bromine pentafluoride in the extraction of oxygen from oxides and silicates for isotopic analysis. Geochimica et Cosmochimica Acta 27, 43-52, doi:10.1016/0016-7037(63)90071-1.

Collo G, Astini RA, Cawood PA, Buchan C and Pimentel M (2009) U-Pb detrital zircon ages and Sm-Nd isotopic features in low-grade metasedimentary rocks of the Famatina belt: Implications for late Neoproterozoic-early Palaeozoic evolution of the proto-Andean margin of Gondwana. Journal of the Geological Society of London 166, 303-319, doi:10.1144/001676492008-051.

Cristofolini EA, Otamendi JE, Ducea MN, Pearson DM, Tibaldi AM and Baliani I (2012) Detrital zircon U-Pb ages of metasedimentary rocks from Sierra de Valle Fértil: Entrapment of Middle and Late Cambrian marine successions in the deep roots of the Early Ordovician Famatinian arc. Journal of South American Earth Sciences 37, 77-94, doi:10.1016/j.jsames.2012.02.001. 
Dahlquist JA, Rapela CW and Baldo EG (2005) Cordierite-bearing S-type granitoids in the Sierra de Chepes (Sierras Pampeanas): Petrogenetic implications. Journal of South American Earth Sciences 20, 231-251, doi:10.1016/j.jsames.2005.05.014.

Dahlquist JA, Pankhurst RJ, Rapela CW, Galindo C, Alasino P, Fanning CM, Saavedra J and Baldo E (2008) New SHRIMP U-Pb data from the Famatina complex: Constraining EarlyMid-Ordovician Famatinian magmatism in the Sierras Pampeanas, Argentina. Geologica Acta 6, 319-333.

Dahlquist JA, Rapela CW, Pankhurst RJ, Fanning CM, Vervoort JD, Hart G, Baldo EG, Murra JA, Alasino P and Colombo F (2012) Age and magmatic evolution of the Famatinian granitic rocks of Sierra de Ancasti, Sierras Pampeanas, NW Argentina. Journal of South American Earth Sciences 34, 10-25.

Dahlquist JA, Pankhurst RJ, Gaschnig RM, Rapela CW, Casquet C, Alasino PH, Galindo C and Baldo E (2013) Hf and Nd isotopes in Early Ordovician to Early Carboniferous granites as monitors of crustal growth in the Proto-Andean margin of Gondwana. Gondwana Research 23, 1617-1630, doi:10.1016/j.gr.2012.08.013.

Davidson JP, Horab JM, Garrison JM and Dungan MA (2005) Crustal forensics in arc magmas Journal of Volcanology and Geothermal Research 140, 157-170

De Paolo D.J. (1981) Trace element and isotopic effects of combined wall rock assimilation and fractional crystallization. Earth Planetary Science Letters 53, 189-202, doi:10.1016/0012$821 X(81) 90153-9$.

De Paolo DJ, Linn AM and Schubert G (1991) The continental crustal age distribution: methods of determining mantle separation ages from $\mathrm{Sm}-\mathrm{Nd}$ isotopic data and application to the 
Southwestern United States. Journal of Geophysical Research 96, 2071-2088, doi:10.1029/90JB02219.

Donnelly T, Waldron S, Tait A, Dougans J and Bearhop S. (2001) Hydrogen isotope analysis of natural abundance and deuterium-enriched waters by reduction over chromium on-line to a dynamic dual inlet isotope-ratio mass spectrometer. Rapid Communications in Mass Spectrometry 15, 1297-1303, doi:10.1002/rcm.361.

Dorendorf F, Wiechert U and Worner G (2000) Hydrated sub-arc mantle: a source for the Kluchevskoy volcano, Kamchatka/Russia. Earth Planetary Science Letters 175, 69-86, doi:10.1016/S0012-821X(99)00288-5.

Ducea MN, Otamendi JE, Bergantz GW, Jianu D and Petrescu L (2015) The origin and petrologic evolution of the Ordovician Famatinian-Puna arc. In Geodynamics of a Cordilleran Orogenic System: The Central Andes of Argentina and Northern Chile. (eds. PG DeCelles, MN Ducea, B Carrapa and PA Kapp), Geological Society of America Memoir 212, 125-138, doi:10.1130/2015.1212(07).

Ducea MN, Bergantz GW, Crowley JL and Otamendi J (2017) Ultrafast magmatic buildup and diversification to produce continental crust during subduction. Geology, doi: $10.1130 / \mathrm{G} 38726.1$.

Eiler JM, McInnes B, Valley JW, Graham CM and Stolper E.M (1998) Oxygen isotope evidence for slab derived fluids in the sub-arc mantle. Nature 393, 777-781, doi:10.1038/31679.

Evans OC \& Hanson GN (1996) Post-kinematic Archean tonalites, trondhjemites, and granodiorites of the S.W. Superior province: derivation through direct mantle melting. In: L.D. Ashwal and M.J. de Wit (Eds). The Tectonic Evolution of Greenstone Belts. Oxford University Press, Oxford. 
Faure G (1986) Principles of isotope geology, Second Edition. John Wiley \& Sons. 589 pp.

Gallien F, Mogessie A, Bjerg E, Delpino S, Castro de Machuca B, Thöni M and Klötzli U (2010) Timing and rate of granulite facies metamorphism and cooling from multi-mineral chronology on migmatitic gneisses, Sierras de La Huerta and Valle Fértil NW Argentina. Lithos 114, 229-52, doi: 10.1016/j.lithos.2009.08.011.

Gallien F, Mogessie A, Hauzenberger CA, Bjerg E, Delpino S and Castro de Machuca B (2012) On the origin of multi-layer coronas between olivine and plagioclase at the gabbro-granulite transition, Valle Fértil-La Huerta Ranges, San Juan Province, Argentina. Journal of Metamorphic Geology 30, 281-02, doi: 10.1111/j.1525-1314.2011.00967.x.

Gill JB (1981) Orogenic andesites and plate tectonics. Springer-Verlag, New York, pp 390.

Godfrey JD (1962) The deuterium content of hydrous minerals from the East Central Sierra Nevada and Yosemite National Park. Geochimica et Cosmochimica Acta 26, 1215-1245.

Gonzaga RG, Lowry D, Jacob DE, LeRoex A, Schulze D and Menzies MA (2010) Eclogites and garnet pyroxenites: Similarities and differences. Journal of Volcanology and Geothermal Research 190, 235-247.

Grosse P, Bellos LI, de los Hoyos CR, Larrovere MA, Rossi JN and Toselli AJ (2011) Acrossarc variation of the Famatinian magmatic arc (NW Argentina) exemplified by I-, S- and transitional I/S-type Early Ordovician granitoids of the Sierra de Velasco. Journal of South American Earth Sciences 32, 110-126, doi:10.1016/j.jsames.2011.03.014.

Grove TL, Elkins-Tanton LT, Parman SW, Chatterjee N, Müntener O and Gaetani GA (2003) Fractional crystallization and mantle-melting controls on calc-alkaline differentiation trends. Contributions to Mineralogy and Petrology 145, 515-533, doi:10.1007/s00410-003-0448-z. 
Grove TL, Till CB and Krawczynski MJ (2012) The Role of $\mathrm{H}_{2} \mathrm{O}$ in Subduction Zone Magmatism. Annual Review of Earth and Planetary Sciences 40, 413-439, doi:10.1146/annurev-earth-042711-105310.

Harmon RS \& Hoefs J (1995) Oxygen isotope heterogeneity of the mantle deduced from global ${ }^{18} \mathrm{O}$ systematics of basalts from different geotectonic settings. Contributions to Mineralogy and Petrology 120, 95-114, doi:10.1007/BF00311010.

Hildreth W \& Moorbath S (1988) Crustal contributions to arc magmatism in the Andes of Central Chile. Contributions to Mineralogy and Petrology 98, 455-489, doi:10.1007/BF00372365.

Hoefs J (2009) Stable Isotope Geochemistry: Berlin, Springer-Verlag, pp. 285.

Jagoutz O and Klein B (2018) On the importance of crystallization-differentiation for the generation of $\mathrm{SiO}_{2}$-rich melts and the compositional build-up of arc (and continental) crust. American Journal of Science 318, 29-63, doi:10.2475/01.2018.03.

James DE (1981) The combined use of oxygen and radiogenic isotopes as indicators of crustal contamination. Annual Review of Earth and Planetary Sciences 9, 311-344

Lackey JS, Valley JW, Chen JH and Stockli DF (2008) Dynamic Magma Systems, Crustal Recycling, and Alteration in the Central Sierra Nevada Batholith: the Oxygen Isotope Record. Journal of Petrology 49, 1397-1426, doi:10.1093/petrology/egn030.

Liu CZ, Wu FY, Chung SL, Li QL, Sun WD and Ji WQ (2014) A 'hidden' 18 O enriched reservoir in the sub-arc mantle. Scientific Reports 4, doi:10.1038/srep04232.

Larrovere MA, de los Hoyos CR, Willner AP, Verdecchia SO, Baldo EG, Casquet C, Basei MA, Hollanda MH, Rocher S, Alasino PH and Moreno GG (2019) Mid-crustal deformation in a 
continental margin orogen: structural evolution and timing of the Famatinian Orogeny, NW Argentina. Journal of the Geological Society, doi.org/10.1144/jgs2018-230.

Moorbath S (1975) Evolution of Precambrian crust from strontium evidence. Nature 254, 395398.

Murra JA and Baldo EG (2006) Evolución tectonotermal ordovícica del borde occidental del arco magmático Famatiniano: metamorfismo de las rocas máficas y ultramáficas de la Sierra de la Huerta-de Las Imanas (Sierras Pampeanas, Argentina). Revista geológica de Chile 33, 277-98, doi: 10.4067/S0716-02082006000200004.

Müntener $\mathrm{O}$, Kelemen $\mathrm{PB}$ and Grove TL (2001) The role of $\mathrm{H}_{2} \mathrm{O}$ during crystallization of primitive arc magmas under uppermost mantle conditions and genesis of igneous pyroxenites: an experimental study. Contributions to Mineralogy and Petrology 141, 643-658, doi:10.1007/s004100100266.

Otamendi JE, Vujovich GI, de la Rosa JD; Tibaldi AM, Castro A, Martino RD and Pinotti LP (2009) Geology and petrology of a deep crustal zone from the Famatinian paleo-arc, Sierras de Valle Fértil and La Huerta, San Juan, Argentina. Journal of South American Earth Sciences 27, 258-279, doi:10.1016/j.jsames.2008.11.007.

Otamendi JE, Ducea MN and Bergantz GW (2012) Geological, petrological and geochemical evidence for progressive construction of an arc crustal section, Sierra de Valle Fértil, Famatinian arc, Argentina. Journal of Petrology 53, 761-800, doi:10.1093/petrology/egr079

Pankhurst RJ, Rapela CW and Fanning CM (2000) Age and origin of coeval TTG, I- and S-type granites in the Famatinian belt of NW Argentina. Transactions of the Royal Society of Edinburgh Earth Sciences 91, 151-168, doi:10.1017/S0263593300007343. 
Ramacciotti CD, Casquet C, Baldo EG, Alasino PH, Galindo C and Dahlquist JA (2019) Late Cambrian - Early Ordovician magmatism in the Sierra de Pie de Palo, Sierras Pampeanas (Argentina): implications for the early evolution of the proto-Andean margin of Gondwana. Geological Magazine, doi:10.1017/S0016756819000748.

Rapela CW, Coira B, Toselli A and Saavedra J. (1992) The lower paleozoic magmatism of southwestern Gondwana and the evolution of famatinian orogen. International Geology Review 34, 1081-1142, doi:10.1080/00206819209465657.

Rapela CW, Verdecchia SO, Casquet C, Pankhurst RJ, Baldo EG, Galindo C, Murra JA, Dahlquist JA and Fanning CM (2016) Identifying Laurentian and SW Gondwana sources in the Neoproterozoic to early Paleozoic metasedimentary rocks of the Sierras Pampeanas: Paleogeographic and tectonic implications. Gondwana Research 32, 193-201, doi:10.1016/j.gr.2015.02.010.

Rapela CW, Pankhurst RJ, Casquet C, Dahlquist JA, Fanning MC, Baldo EG, Galindo C, Alasino PH, Ramacciotti CD, Verdecchia SO, Murra JA and Basei MAS. (2018) A review of the Famatinian Ordovician magmatism in southern South America: evidence of lithosphere reworking and continental subduction in the early proto-Andean margin of Gondwana. EarthScience Review 187, 259-285, doi:10.1016/j.earscirev.2018.10.006.

Rapp RP, Watson EB and Miller CF (1991) Partial melting of amphibolite/eclogite and the origin of Archean trondhjemites and tonalites. Precambrian Research 51: 1-25, doi:10.1016/0301-9268(91)90092-O.

Rogers G \& Hawkesworth CJ (1989) A geochemical traverse across the North Chilean Andes: evidence for crust generation from the mantle wedge. Earth Planetary Science Letters 91, 271-285, doi:10.1016/0012-821X(89)90003-4. 
Rossi JN \& Toselli AJ (2005) Paleozoic ages and intrusivity of granitoids in the Velasco Range, Argentina. $19^{\circ}$ Colloquium on Latin American Geosciences. Terra Nostra 05/1, 103-104.

Rumble D, Liou JG and Jahn BM (2003) Continental crust subduction and ultrahigh-pressure metamorphism. In The crust (ed. RL Rudnick), Treatise on geochemistry (eds. HD Holland and KK Turekian). Oxford, Elsevier, p. 293-319.

Saavedra J, Pellitero E, Rossi J and Toselli A (1992) Magmatic evolution of the Cerro Toro granite, a complex Ordovician pluton of northwestern Argentina. Journal of South American Earth Sciences 5, 21-32, doi:10.1016/0895 -9811(92)90057-6.

Saunders AD, Norry MJ and Tarney NJ (1988) Origin of MORB and chemically-depleted mantle reservoirs: Trace element constraints: Journal of Petrology, Special Vol. 1, 415-445, doi:10.1093/petrology/Special_Volume.1.415.

Sharp ZD (1990) A laser-based microanalytical method for in situ determination of oxygen isotope ratios of silicates and oxides. Geochimica et Cosmochimica Acta 54, 1353-1357, doi:10.1016/0016-7037(90)90160-M.

Stracke A. (2012) Earth's heterogeneous mantle: A product of convection-driven interaction between crust and mantle. Chemical Geology 330-331, 274-299, doi:10.1016/j.chemgeo.2012.08.007.

Tibaldi AM, Otamendi JE, Cristofolini EA, Baliani I, Walker BA and Bergantz GW (2013) Reconstruction of the Early Ordovician Famatinian arc through thermobarometry in lower and middle crustal exposures, Sierra de Valle Fértil, Argentina. Tectonophysics 589, 151-66, doi:10.1016/j.tecto.2012.12.032.

Toselli AJ (1992) El magmatismo del noroeste argentino. In: Reseña sistemática e interpretación. Serie Correlación Geológica 8, Tucumán, pp. 243. 
Walker Jr BA, Bergantz GW, Otamendi JE, Ducea MN and Cristofolini EA (2015) A MASH zone revealed: the mafic complex of the sierra Valle Fértil. Journal of Petrology 56, 18631896, doi: 10.1093/petrology/egv057.

Weinberg RF, Becchio R, Farias P, Suzaño N and Sola A (2018) Early Paleozoic accretionary orogenies in NW Argentina: Growth of West Gondwana. Earth-Science Review 187, 219247, doi.org/10.1016/j.earscirev.2018.10.001.

\section{Captions}

Figure 1. Generalized sketch map of the Sierras Pampeanas and southern Puna showing the main lithologies and distribution of the Pampean and Famatinian orogenic belts. The study areas for this work are mostly included within the main region of the Famatinian arc. The pressure value for each crustal section is estimated from the emplacement of magma or the regional metamorphism (see text). Domains of the Famatinian orogen taken from Rapela et al (2018): (FFD) Foreland Famatinian Domain; (EFD) Eastern Famatinian Domain; (CFD) Central Famatinian Domain and (WFD) Western Famatinian Domain.

Figure 2. (a) ${ }^{87} \mathrm{Sr} /{ }^{86} \mathrm{Srt}_{\mathrm{t}}$ vs. $\delta^{18} \mathrm{O} \%$ (WR), (b) $\delta^{18} \mathrm{O} \%$ (Zrn) vs. $\delta^{18} \mathrm{O} \%$ (WR) and (c) ${ }^{143} \mathrm{Nd} /{ }^{144} \mathrm{Nd}$ vs. $\delta^{18} \mathrm{O} \%$ for igneous and metamorphic rocks of the main arc region of the Famatinian orogen. $\delta^{18} \mathrm{O} \%$ (WR): values for whole-rock sample and $\delta^{18} \mathrm{O} \%$ o $(\mathrm{Zrn})$ : values for zircon.

Figure 3. (a) $\delta^{18} \mathrm{O} \%$ vs. ${ }^{143} \mathrm{Nd} /{ }^{144} \mathrm{Nd}$ and (b) ${ }^{143} \mathrm{Nd} /{ }^{144} \mathrm{Nd}$ vs. La/Sm for gabbros and diorites of the main arc region of the Famatinian orogen. Note that trace element ratios involving a moderately incompatible element (e.g., La/Sm in figure b) are dominantly influenced by the 
melting process, whereas the isotope ratios only change in response to the relative contribution of the two source components. The $\mathrm{La} / \mathrm{Sm}$ ratio is sensitive to the presence of residual garnet (and thus the depth of melting and/or the role of pyroxenite) (e.g., Stracke 2012). Data for figure (b): see supplementary data.

Figure 4. (a) ${ }^{87} \mathrm{Sr} /{ }^{86} \mathrm{Srt}$ vs. $\mathrm{K}_{2} \mathrm{O} \%$ and (b) $\mathrm{Sr}$ (ppm) vs. ${ }^{87} \mathrm{Sr} /{ }^{86} \mathrm{Sr}_{\mathrm{t}}$ for igneous and metamorphic rocks of the main arc region of the Famatinian orogen. In (b) a simple mixing-equation based on the $\mathrm{Sr}$ isotope composition is used to estimate the crustal contamination in tonalite (see Table 4a). Data for figures (a) and (b) see supplementary data. Symbols are as figure 2.

Figure 5. $\delta^{18} \mathrm{O} \%$ vs. $\delta \mathrm{D} \%$ for igneous and metamorphic rocks of the main arc region of the Famatinian orogen. Symbols are as figure 2.

Figure 6. Schematic cross-section through the Famatinian continental arc, representing a possible non-homogenized magmatic column with variable contamination both in mid-crustal regional contacts and in the deeper levels. SCLM: subcontinental lithospheric mantle. 
Table 1. Summary of the samples from the Famatinian orogen

\begin{tabular}{|c|c|c|c|c|}
\hline Samples & Lat. (S) & Long. (W) & Locality/Unit/Rock type & Age (Ma) \\
\hline \multicolumn{5}{|l|}{ G1 } \\
\hline$\overline{\text { FAM } 392}$ & 290044 & 680930 & Cerro Toro, W Sierra de Famatina [2], older mafic suite, meta-troctolitic gabbro & -- \\
\hline SVF500 & 304653 & 673437 & W Sierra Valle Fértil [1], older mafic unit, gabbronorite & -- \\
\hline \multicolumn{5}{|c|}{ 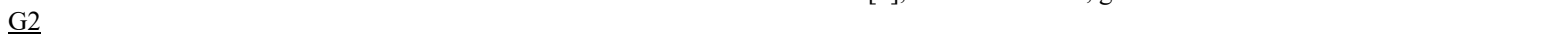 } \\
\hline$\overline{\mathrm{ASP}} 350$ & 290030 & 681412 & Cerro Asperecito, W Sierra de Famatina [2], older mafic suite, hornblende gabbro & -- \\
\hline ASP221 & 290047 & 681409 & Cerro Asperecito, W Sierra de Famatina [2], older mafic suite, hornblende gabbro & -- \\
\hline CTO30003 & 290043 & 680935 & Cerro Toro, W Sierra de Famatina [2], older mafic suite, meta-troctolitic gabbro & -- \\
\hline FAM176 & 290437 & 675650 & Central part of the Sierra de Famatina [5], younger mafic suite, diorite $(\mathrm{Hbl}+\mathrm{Pl})$ & -- \\
\hline SVF501 & 304653 & 673437 & W Sierra Valle Fértil [1], older mafic suite, hornblende gabbro & -- \\
\hline SVF502 & 304653 & 673437 & W Sierra Valle Fértil [1], older mafic suite, gabbro & -- \\
\hline SVF571 & 303928 & 673617 & W Sierra Valle Fértil [1], older mafic suite, gabbro & -- \\
\hline SVF584 & 303413 & 673450 & W Sierra Valle Fértil [1], older mafic suite, gabbronorite & -- \\
\hline SVF591 & 304231 & 672939 & W Sierra Valle Fértil [1], younger mafic suite, hornblende gabbro & -- \\
\hline SVF605 & 304424 & 673441 & W Sierra Valle Fértil [1], older mafic suite, coronitic gabbro & -- \\
\hline SVF3017 & 301258 & 675008 & W Sierra Valle Fértil [1], older mafic suite, hornblende gabbro & -- \\
\hline SFV40039 & 304748 & 673440 & W Sierra Valle Fértil [1], older mafic suite, hornblende gabbro & \\
\hline VCA1007 & 285849 & 681307 & Cerro Asperecito, W Sierra de Famatina [2], younger mafic suite, diorite $(\mathrm{Hbl}+\mathrm{Pl})$ & $467 \pm 3$ \\
\hline VCA7037 & 285939 & 681436 & Cerro Asperecito, W Sierra de Famatina [2], older mafic suite, hornblende gabbro & -- \\
\hline FAM213 & 290156 & 600956 & Cerro Toro, W Sierra de Famatina [2], Cerro Toro tonalite $(\mathrm{Bt}+\mathrm{Hbl})$ & -- \\
\hline SVF508 & 304634 & 673438 & Central part of the Sierra de Valle Fértil [1], intermediate unit, $\mathrm{Bt}+\mathrm{Hbl}$ tonalite & $474 \pm 4$ \\
\hline SVF521 & 305533 & 672108 & Central part of the Sierra de Valle Fértil [1], intermediate unit, Bt tonalite & -- \\
\hline VCA7039 & 285655 & 681601 & Cerro Asperecito, W Sierra de Famatina [2], Cerro Toro tonalite (Bt) & -- \\
\hline NAC256 & 305428 & 662355 & Sierra de Los Llanos [4], Nacate granodiorite $(\mathrm{Hb}+\mathrm{Bt})$ & $474 \pm 3$ \\
\hline FAM303 & 290250 & 680532 & W Sierra de Famatina [2], Ñuñorco granite, Bt monzogranite-granodiorite & -- \\
\hline FAM7083 & 290356 & 675647 & Central part of the Sierra de Famatina [5], Nuñorco granite, Bt monzogranite & $463 \pm 4$ \\
\hline MIR1014 & 292029 & 674622 & E Sierra de Famatina [5], Ñuñorco granite, $\mathrm{Bt}+\mathrm{Hb}$ granodiorite & $478 \pm 4$ \\
\hline CHA3008 & 274744 & 680310 & Sierra de Las Planchadas [6], Chaschuil rhyolite & $468 \pm 3$ \\
\hline FAM7081 & 290217 & 675604 & Central part of the Sierra de Famatina [5], Potrero Grande rhyolite & $477 \pm 4$ \\
\hline FAM40025 & 285306 & 673048 & E Sierra de Famatina [5], metarhyolite & \\
\hline TUA1028 & 310800 & 663250 & Sierra de Los Llanos [4], Tuaní leucogranite & $482 \pm 3$ \\
\hline ANC11030a & 290930 & 652950 & Sierra de Ancasti [8], Las Cañadas tonalite (Bt) & $466 \pm 6$ \\
\hline ANC11022 & 290930 & 652950 & Sierra de Ancasti [8], Las Cañadas granite, Bt monzogranite & $470 \pm 5$ \\
\hline \multicolumn{5}{|c|}{ 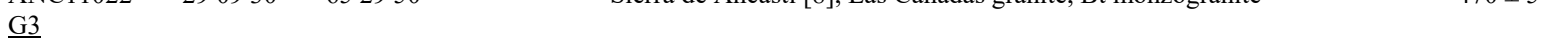 } \\
\hline$\overline{\text { FAM332 }}$ & 290132 & 681034 & Cerro Toro, W Sierra de Famatina [2], Bt tonalite & -- \\
\hline FAM7086 & 290125 & 681019 & Cerro Toro, W Sierra de Famatina [2], Bt tonalite & $481 \pm 4$ \\
\hline G4 & & & Sierra Valle Fértil [1], Crd gneiss & \\
\hline$\overline{\text { FAM } 339}$ & 290035 & 680952 & Cerro Toro, W Sierra de Famatina [2], Crd + Grt migmatite & -- \\
\hline FAM 349 & 290033 & 681418 & Cerro Asperecito, W Sierra de Famatina [2], migmatite & -- \\
\hline FAM 391 & 285924 & 681552 & Cerro Asperecito, W Sierra de Famatina [2], migmatitic gneiss & -- \\
\hline SVF709 & 311717 & 673200 & Lomas de Las Chacras [7], W Sierra de Valle Fértil, migmatite & -- \\
\hline SVF515 & 304527 & 673505 & Sierra Valle Fértil [1], cordierite gneiss & \\
\hline TUA1029 & 310800 & 663250 & Sierra de Los Llanos [4], Tuaní cordierite monzogranite & $486 \pm 7$ \\
\hline VEL1026 & 292049 & 671508 & SW Sierra de Velasco [3], La Puerta Bt monzogranite & $482 \pm 3$ \\
\hline VEL3000 & 291733 & 671009 & SW Sierra de Velasco [3], Crd monzogranite & $481 \pm 3$ \\
\hline
\end{tabular}


Table 2. O-H isotopic compositions from studied

\begin{tabular}{|c|c|c|c|}
\hline $\begin{array}{l}\text { Group } \\
\text { samples }\end{array}$ & $\begin{array}{l}\text { Rock } \\
\text { type }\end{array}$ & $\begin{array}{c}\delta^{18} O \\
(\% 0)\end{array}$ & $\begin{array}{l}\delta D \\
(\% o)\end{array}$ \\
\hline & \multicolumn{3}{|c|}{ ARC SAMPLES } \\
\hline \multicolumn{4}{|l|}{ G1 } \\
\hline FAM392 ${ }^{+}$ & metagabbro & +5.3 & -113 \\
\hline SVF500 ${ }^{(2)}$ & gabbronorite & +5.3 & \\
\hline \multicolumn{4}{|l|}{$\mathrm{G} 2$} \\
\hline$\overline{\mathrm{ASP}} 350^{(2)}$ & gabbro & +8.0 & \\
\hline $\operatorname{ASP} 221^{+}$ & gabbro & +9.2 & \\
\hline CTO30003 $3^{(2)}$ & gabbro & +6.6 & \\
\hline FAM $176^{+}$ & diorite & +6.8 & -76 \\
\hline SVF501 ${ }^{(2)}$ & gabbronorite & +8.0 & \\
\hline SVF502 ${ }^{(2)}$ & gabbro & +8.4 & \\
\hline SVF571 ${ }^{(2)}$ & gabbro & +9.4 & \\
\hline SVF584 ${ }^{(2)}$ & gabbronorite & +8.1 & \\
\hline SVF591 ${ }^{(2)}$ & gabbro & +8.0 & \\
\hline SVF605 $5^{(2)}$ & metagabbro & +7.5 & \\
\hline SVF3017 $7^{(2)}$ & gabbro & +7.4 & \\
\hline SFV40039 ${ }^{(1)}$ & gabbro & +7.5 & -93 \\
\hline VCA $1007^{+}$ & diorite & +8.1 & -82 \\
\hline VCA7037(2) & gabbro & +9.0 & -58 \\
\hline FAM $213^{+}$ & tonalite & +7.8 & \\
\hline SVF508 ${ }^{(1)}$ & tonalite & +8.6 & -101 \\
\hline SVF52 $1^{(2)}$ & tonalite & +9.0 & \\
\hline VCA7039(2) & tonalite & +9.3 & \\
\hline NAC $256^{(1)}$ & granodiorite & +9.1 & -73 \\
\hline FAM7083 $3^{(2)}$ & monzogranite & +8.5 & \\
\hline MIR1014 ${ }^{(1)}$ & granodiorite & +7.8 & -68 \\
\hline CHA3008 ${ }^{(1)}$ & rhyolite & +8.9 & -75 \\
\hline FAM7081 $1^{(2)}$ & rhyolite & +9.4 & \\
\hline FAM40025 $5^{(1)}$ & metarhyolite & +6.2 & -82 \\
\hline TUA1028 $8^{(1)}$ & leucogranite & +9.5 & -79 \\
\hline ANC11030a $\mathrm{a}^{(1)}$ & tonalite & +9.2 & -99 \\
\hline ANC11022 $2^{(1)}$ & monzogranite & +8.7 & -72 \\
\hline \multicolumn{4}{|l|}{ G3 } \\
\hline$\overline{\text { FAM } 332^{+}}$ & tonalite & +9.9 & -93 \\
\hline FAM7086 $6^{(2)}$ & tonalite & +8.7 & \\
\hline \multicolumn{4}{|l|}{$\mathrm{G} 4$} \\
\hline$\overline{\text { FAM }} 339^{+}$ & migmatite & +10.5 & -124 \\
\hline FAM $349^{(1)}$ & migmatite & +14.7 & -72 \\
\hline FAM $391^{+}$ & gneiss & +13.8 & -69 \\
\hline SVF709 $9^{(1)}$ & migmatite & +10.9 & -77 \\
\hline SVF515 $5^{(1)}$ & gneiss & +11.2 & -104 \\
\hline TUA1029(1) & monzogranite & +11.8 & -75 \\
\hline VEL1026 $6^{(1)}$ & monzogranite & +10.2 & -104 \\
\hline VEL3000 ${ }^{(1)}$ & monzogranite & +10.5 & -71 \\
\hline \multicolumn{4}{|c|}{$\begin{array}{l}\text { (1) Samples analyzed at the Scottish Universities } \\
\text { Environmental Research Centre (UK). (2) Samples } \\
\text { analyzed at the Servicio General de Análisis de } \\
\text { Isótopos Estables (University of Salamanca, Spain). } \\
\text { SAMPLE }{ }^{+} \text {isotopic composition from Alasino et al. } \\
\text { (2016). }\end{array}$} \\
\hline
\end{tabular}


Table 3. Zircon O and whole rock $\mathrm{Sr}-\mathrm{Nd}$ isotopic compositions from studied samples

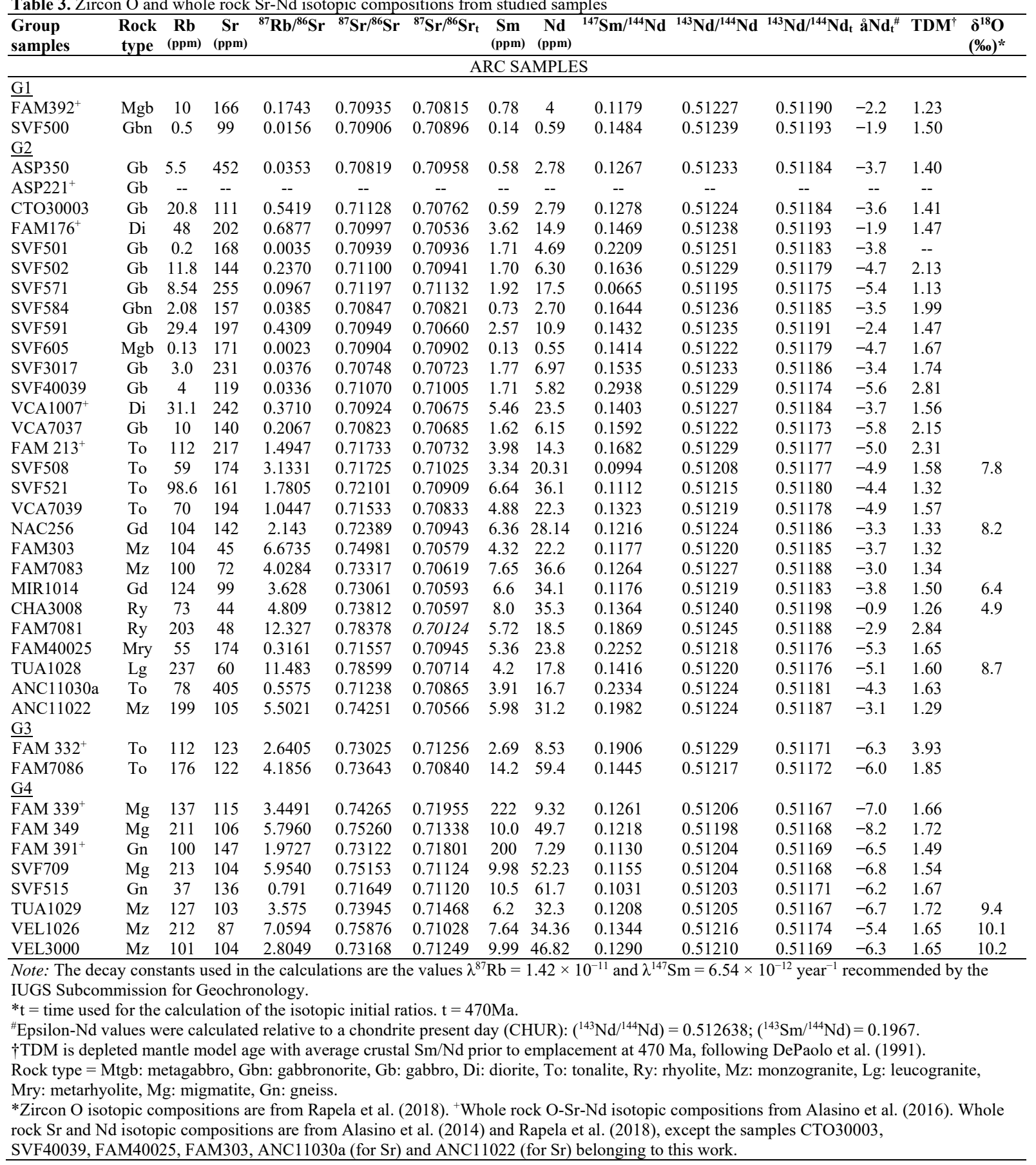


Table 4.

a) Two-component mixtures using equation 9.1 from Faure (1986, page 141).

(1) $X_{M}=f\left(X_{A}-X_{B}\right)+X_{B} \quad G 3$ hybr

(2) $X_{M}-X_{B}=f\left(X_{A}-X_{B}\right)$

G3 hybrid samples

(3) $\mathrm{X}_{\mathrm{M}}-\mathrm{X}_{\mathrm{B}} /\left(\mathrm{X}_{\mathrm{A}}-\mathrm{X}_{\mathrm{B}}\right)=f$

$\mathrm{X}_{\mathrm{A}}=0.7078$ (average of two tonalites from Cerro Toro: FAM213 and VCA7039)

$\mathrm{X}_{\mathrm{B}}=0.7169$ (average of three metasedimentary rocks from Cerro Toro: FAM 339, FAM

349 and FAM 391)

$\mathrm{X}_{\mathrm{M}}=0.7084$ (sample FAM7086) $\quad f=95 \%$

$\mathrm{X}_{\mathrm{M}}=0.7125$ (sample FAM332) $\quad f=61 \%$

Mixing model in figure $4 \mathrm{~b}$

$\mathrm{X}_{\mathrm{A}}=0.7076$ (average of three tonalites: FAM175, FAM213 and KS128A)

$\mathrm{X}_{\mathrm{B}}=0.7216$ (the more radiogenic composition of the metasedimentary rock: KS064B)

$\mathrm{X}_{\mathrm{M}}=0.7073 \quad f=100 \%$

$\mathrm{X}_{\mathrm{M}}=0.7109 f=75 \%$

$\mathrm{X}_{\mathrm{M}}=0.7145 \quad f=50 \%$

$\mathrm{X}_{\mathrm{M}}=0.7181 \quad f=25 \%$

$\mathrm{X}_{M}=0.7216 \quad f=0 \%$

b) Mass-balance mixing equation

(4) $\delta^{18} \mathrm{O}_{m}=(1-x) \delta^{18} \mathrm{O}_{m}{ }_{m}+x \delta^{18} \mathrm{O}_{\mathrm{c}}$

G3 hybrid samples

$\delta^{18} \mathrm{O}^{\circ}{ }_{m}=+7.8 \%$ (sample FAM213)

$\delta^{18} \mathrm{O}_{\mathrm{c}}=+13 \%$ (average of three metasedimentary rocks: FAM 339, FAM 349 and FAM

391)

$\delta^{18} \mathrm{O}_{m}=8.7 \%$ o (sample FAM7086) $x=5 \%$

$\delta^{18} \mathrm{O}_{m}=9.0 \%$ (sample FAM332) $x=40 \%$

Mixing model

$\delta^{18} \mathrm{O}_{m}^{\circ}=7.8 \%$ (sample FAM213)

$\delta^{18} \mathrm{O}_{\mathrm{c}}=12.6 \%$ (average of five metasedimentary rocks of Table 2)

$\delta^{18} \mathrm{O}_{m}=9 \%, x=25 \%$

a) $\mathrm{X}_{\mathrm{A}}$ is the initial $\mathrm{Sr}$ isotopic ratio $\left({ }^{87} \mathrm{Sr}{ }^{86} \mathrm{Sr}_{\mathrm{t}}\right)$ of the starting magma; $\mathrm{X}_{\mathrm{B}}$ is the initial $\mathrm{Sr}$ isotopic ratio of the contaminant; $\mathrm{X}_{\mathrm{M}}$ is the isotopic assumed mixed composition represented by studied samples of the Famatinian arc; $f=$ the starting magma fraction in the mixture. Data used in the calculation from table 3 and supplementary data.

b) $\delta^{18} \mathrm{O}_{m}^{\circ}$ is the oxygen isotope composition of the starting magma; $\delta^{18} \mathrm{O}_{\mathrm{c}}$ is the oxygen isotope composition of the contaminant;

$\delta^{18} \mathrm{O}_{m}$ is the isotopic assumed mixed composition; $x$ is the mass fraction of the component $\mathrm{c}$. Data used in the calculation from table 2 . 
Figure 1. Alasino et al.

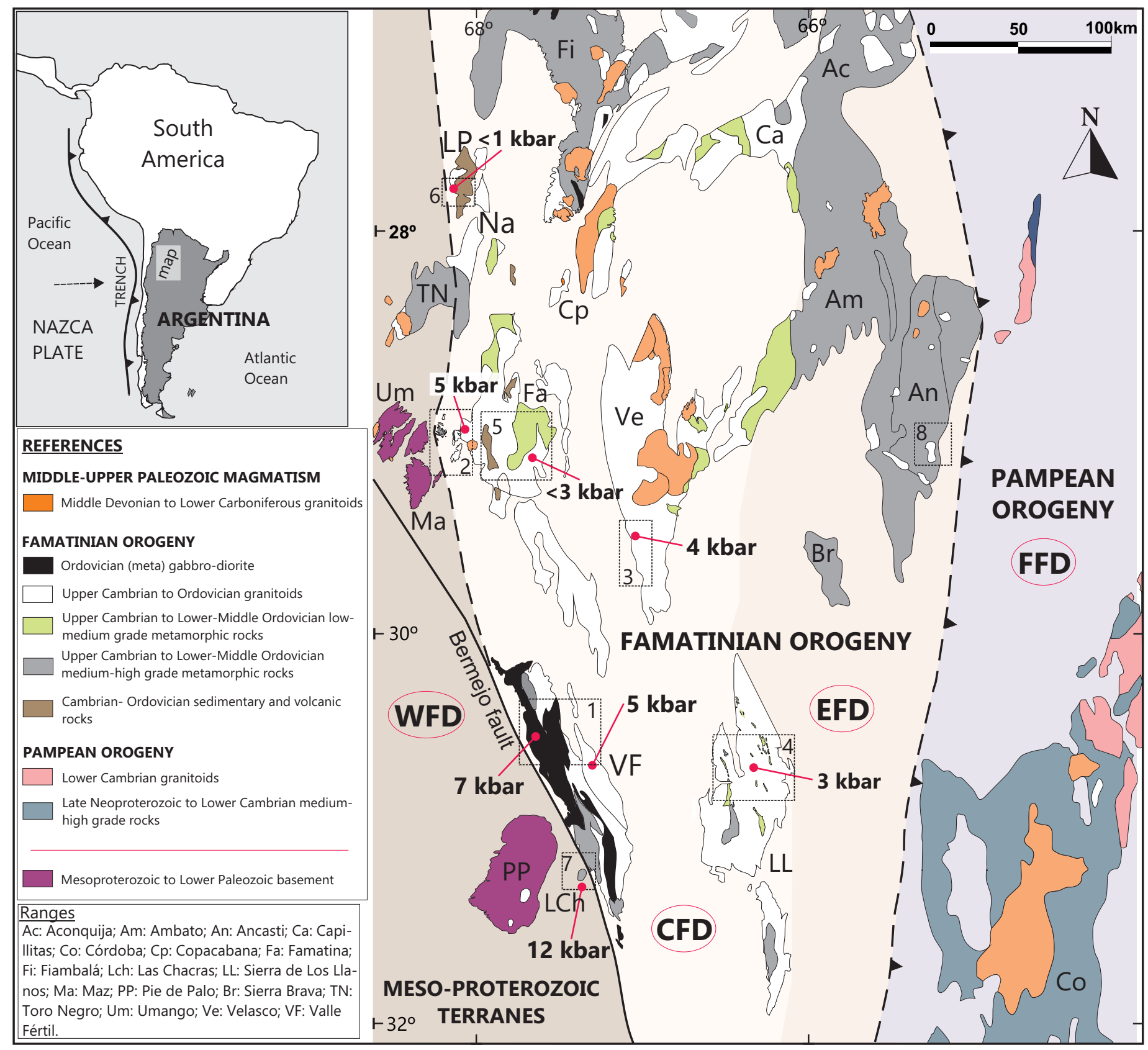


Figure 2. Alasino et al.
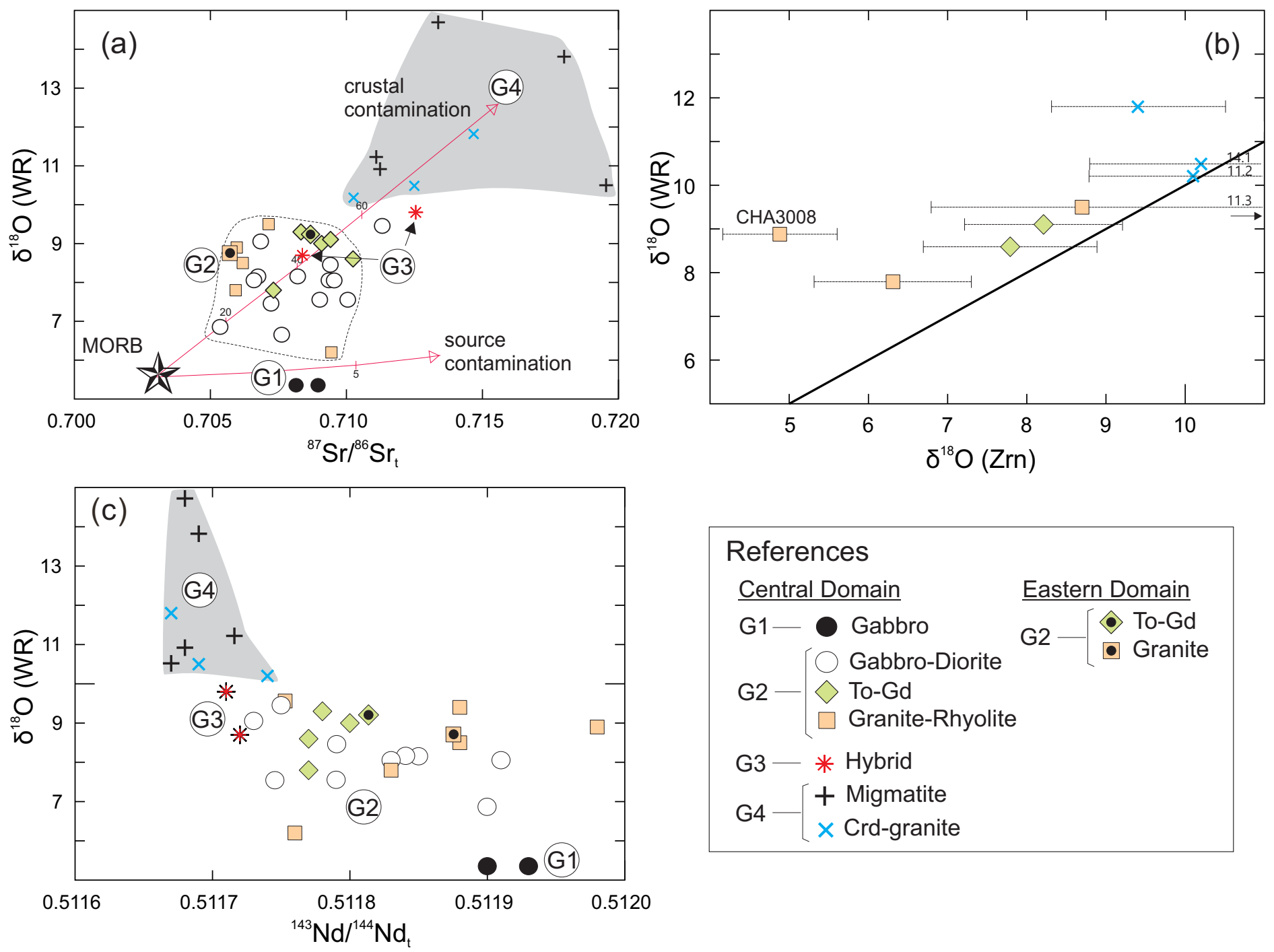
Figure 3. Alasino et al.
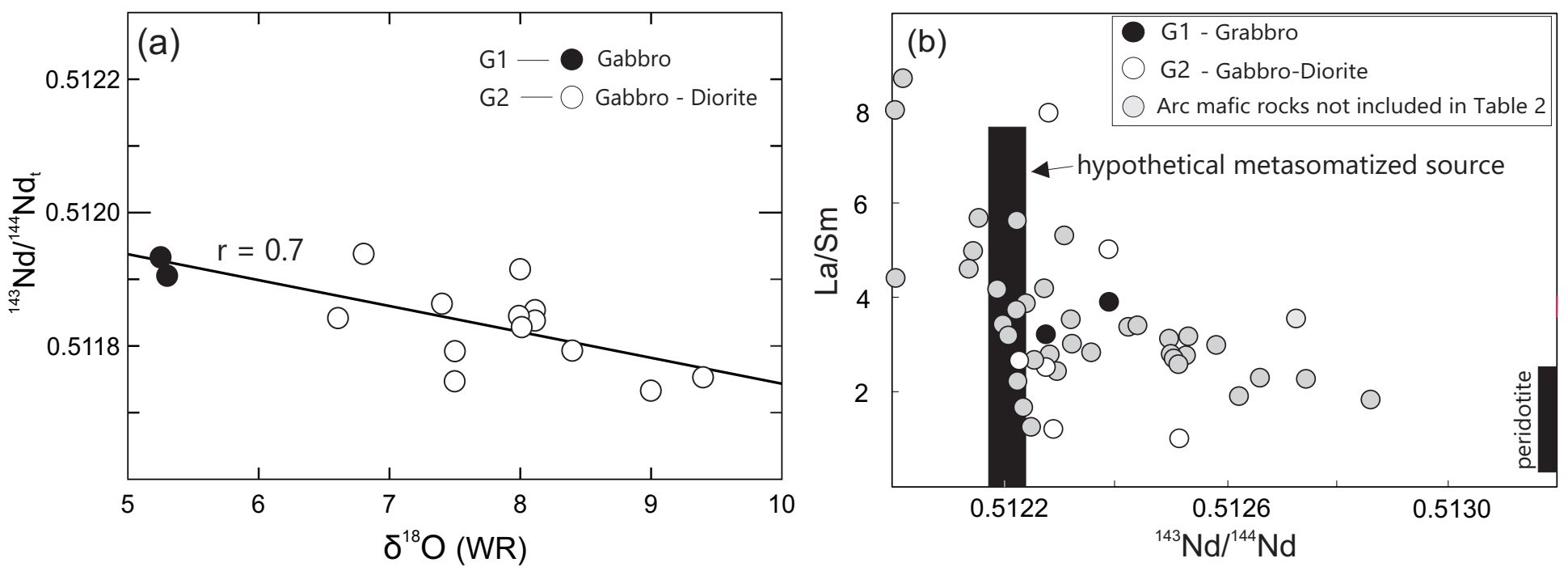
Figure 4. Alasino et al.
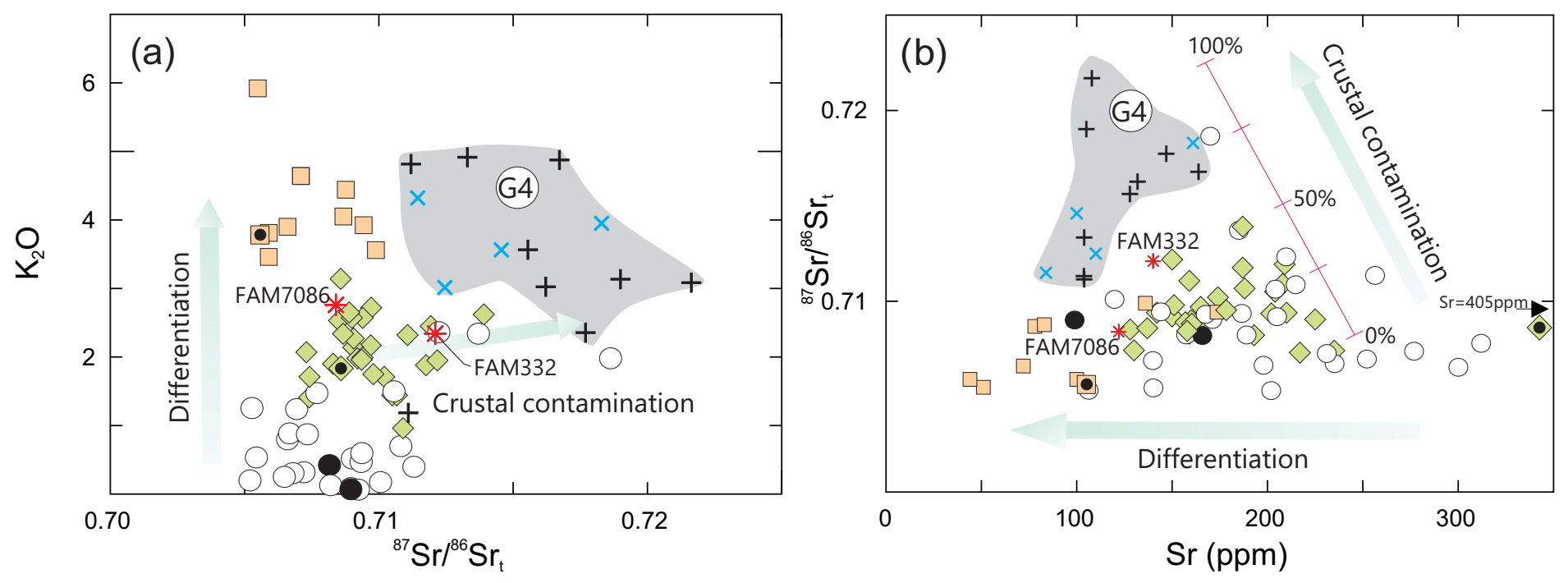
Figure 5. Alasino et al.

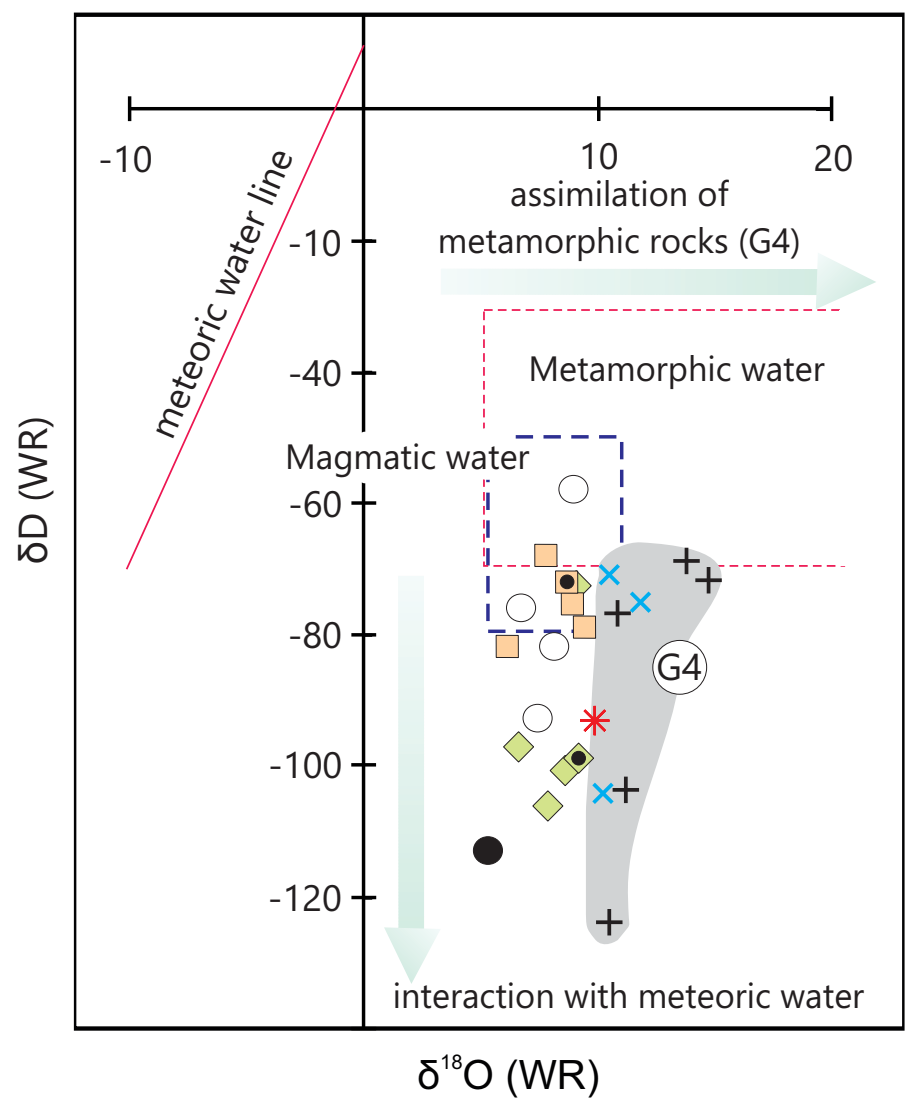


Figure 6. Alasino et al.

\section{Representative arc lithospheric section}

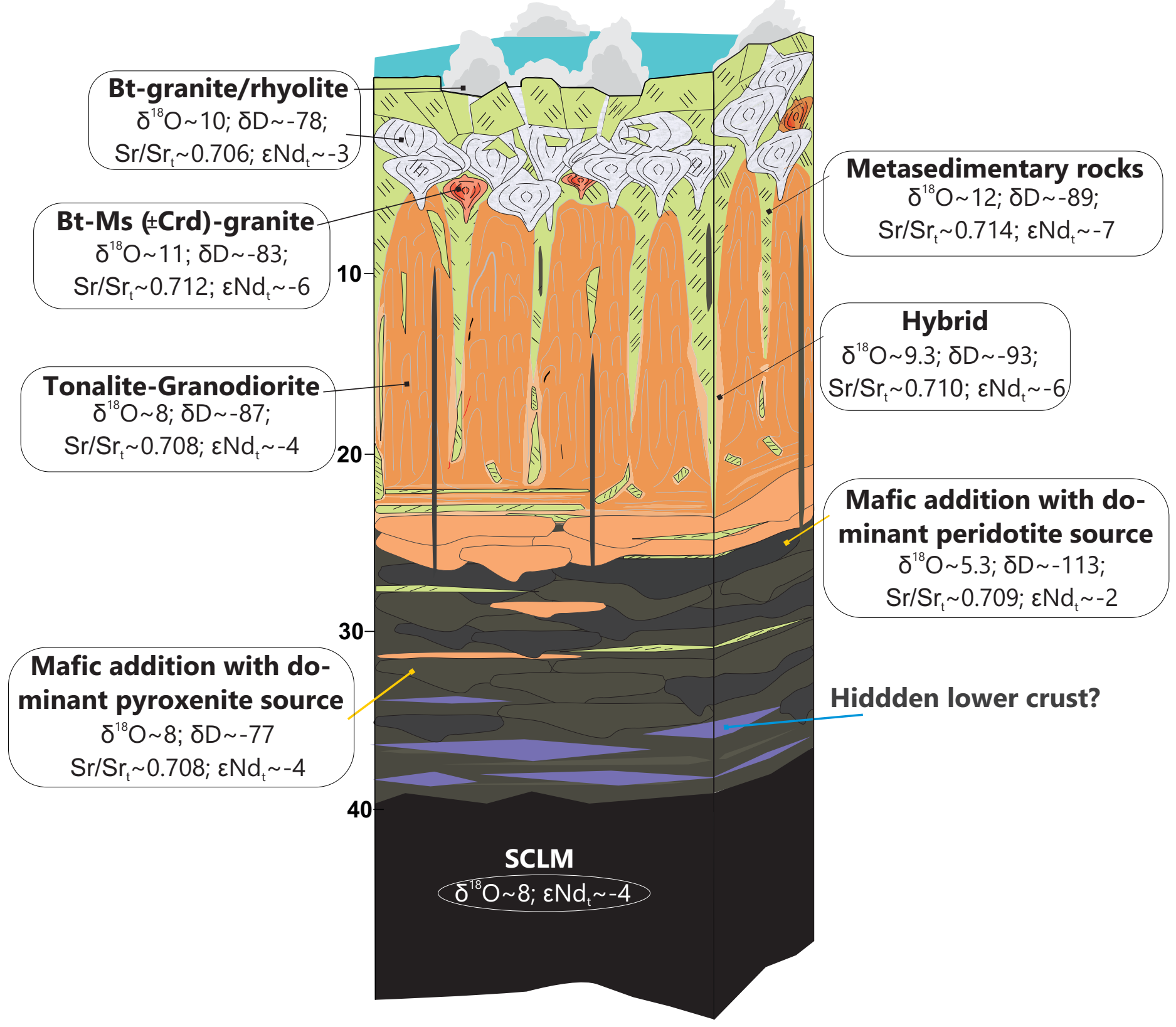

